\title{
Inhibition of Ostwald ripening through surface switching species during potentiodynamic dissolution of platinum nanoparticles as an efficient strategy for platinum group metal (PGM) recovery
}

Sharma, Raghunandan; Simonsen, Søren Bredmose; Morgen, Per; Andersen, Shuang Ma

Published in:

Electrochimica Acta

Link to article, DOI:

10.1016/j.electacta.2019.134662

Publication date:

2019

Document Version

Peer reviewed version

Link back to DTU Orbit

Citation (APA):

Sharma, R., Simonsen, S. B., Morgen, P., \& Andersen, S. M. (2019). Inhibition of Ostwald ripening through surface switching species during potentiodynamic dissolution of platinum nanoparticles as an efficient strategy for platinum group metal (PGM) recovery. Electrochimica Acta, 321, [134662].

https://doi.org/10.1016/j.electacta.2019.134662

\section{General rights}

Copyright and moral rights for the publications made accessible in the public portal are retained by the authors and/or other copyright owners and it is a condition of accessing publications that users recognise and abide by the legal requirements associated with these rights.

- Users may download and print one copy of any publication from the public portal for the purpose of private study or research.

- You may not further distribute the material or use it for any profit-making activity or commercial gain

- You may freely distribute the URL identifying the publication in the public portal 


\title{
Inhibition of Ostwald ripening through surface switching species
}

\section{during potentiodynamic dissolution of platinum nanoparticles as an} efficient strategy for platinum group metal (PGM) recovery

\author{
Raghunandan Sharma ${ }^{1 *}$, Søren Bredmose Simonsen ${ }^{2}$, Per Morgen ${ }^{1}$, and Shuang Ma Andersen ${ }^{1 *}$ \\ ${ }^{1}$ Department of Chemical Engineering, Biotechnology and Environmental Technology, University \\ of Southern Denmark, Campusvej 55, DK-5230 Odense M, Denmark \\ ${ }^{2}$ Technical University of Denmark, Department of Energy Conversion and Storage, \\ Frederiksborgvej 399, 4000 Roskilde, Denmark
}

Corresponding authors: mashu@kbm.sdu.dk (S.M.A), sharmariitk@gmail.com (R.S.)

\begin{abstract}
Efficient recovery of platinum group metals (PGMs) from industrial spent catalysts through electrochemical means using mild conditions is of significant importance from both the industrial and the environmental points of view. Owing to their large surface-to-volume ratio, fast dissolution of PGM nanoparticles is possible through potential cycling between oxidizing and reducing potentials, leading to formation and dissolution of surface-oxide layer (transient dissolution). However, at reducing potentials, reduction of the dissolved metal species on the source nanoparticles leads to enhance the Ostwald ripening process and hence to decrease the overall dissolution efficiency significantly. We report a new concept to accelerate dissolution of $\mathrm{Pt}$ nanoparticles by use of surface switching species (SSS), e.g. Cu ions, functioning to selectively
\end{abstract}


block the Pt surface to inhibit redeposition induced particle growth at reducing condition and expose the Pt surface to facilitate dissolution at oxidation condition, respectively. The presence of SSS during potential cycling enhances Pt dissolution by a factor of 2 or more as compared to that without SSS. Such surface self-relegation property to depress unwanted process and assist desired reaction documents an alternative and efficient approach for precious metal electrochemical recovery in dilute acidic baths with/without complexing agents.

Keywords: Platinum dissolution, Recycling, Nanoparticle, Ostwald ripening, Inhibition

\section{Introduction}

Platinum group metals (PGMs), including Platinum, Palladium, Ruthenium, Iridium, Rhodium, Osmium, in nanoparticle form are of significant industrial importance in applications such as catalysts for exhaust gas purification in fossil fuel powered vehicles or systems, organic chemical reactions as well as renewable energy conversion including fuel cells and electrolyzer cells [1-6]. PGMs are known as one of the critical raw materials, and access to the natural reserves is dominated by South Africa and Russia [7]. However, the supply reliability of the PGMs turned out not to be related to the resource depletion, but to social, economic and environmental in nature [8], since PGM secondary production or recycling and its related behaviors play a substantial role in the PGM supply chain.

Recovery of PGM through conventional pyrometallurgical or hydrometallurgical routes is commonly used for PGM extraction and it has operated on commercial scale by world leading chemical plants for the past 40 years [8]. However, the extraction process based on smelting and refinery is of production risk due to the reliability of the infrastructure related to the classical 
technology (requiring continuous operation and constant maintenance), large energy consumption (operating up to $1350{ }^{\circ} \mathrm{C}$ ) [9] and environmental impact (releasing $\mathrm{SO}_{2}, \mathrm{NO}_{\mathrm{x}}$, greenhouse gases, and using corrosive and toxic chemicals [10-12] such as aqua regia $\left(\mathrm{HCl} / \mathrm{HNO}_{3}\right)$, piranha solution $\left(\mathrm{H}_{2} \mathrm{SO}_{4} / \mathrm{H}_{2} \mathrm{O}_{2}\right)$ etc.). Alternative technologies are desperately needed to complement and finally replace the traditional PGM recovery technologies.

Owing to their high activity, recovery of the nanoparticulate PGMs through more industrially simple and environmentally friendly means is of significant interest [13]. With the advance of the scientific knowledge and analytical techniques, electrochemical dissolution of PGM nanoparticles utilizing their surface chemical and electronic properties to extract, dissolve and separate PGMs from other components was proven by several initiatives [13-15], which has demonstrated a pioneer advance in comparison to the classic method of separation based on physical properties of melting point and density [16-18]. Electrochemical dissolution under transient conditions through potential cycling between oxidizing and reducing potentials leading to formation and dissolution of metaloxide layers may provide an alternative industrial process for fast recovery of PGM nanoparticles [19].

Formation of the PGM soluble species (e.g. $\left[\mathrm{PtCl}_{4}\right]^{2-}$ and $\left[\mathrm{PtCl}_{6}\right]^{2-}$ complexes in case of $\mathrm{Pt}$ ) by dissolving the metal-oxide layer completely at a high rate industrial interest generally requires the potential to be lowered significantly below their standard reduction potentials $\left(\mathrm{E}^{\circ}\right)$. This renders a redeposition of the PGM soluble species on energy favorable sites, such as metal nanoparticles (especially PGMs), and has also been reported for nitrogen doped carbon species [20].

This redeposition of the PGM soluble species leads to the growth of the nanoparticles, which is well known as Ostwald ripening and has been reported by several groups [21-25]. Such dissolution and redeposition processes significantly reduces PGM dissolution efficiency, as illustrated in Fig. 1a. 
This PGM dissolution-redeposition phenomenon might appear less significant under a dynamic condition or a flow cell configuration (in combination with highly sensitive analyzing techniques), as practiced by several groups $[26,27]$. Since the dissolved species in proximity of the working electrode are carried away for analysis and therefore they can less likely participate in further redeposition. However, in a realistic static situation, the thermodynamic-driven spontaneous process to reduce surface energy contributes significantly in redeposition of the soluble species and causes a reduced dissolution efficiency. To overcome the above-described process, there are three rational solutions:

- To stabilize dissolved metal species to reduce the possibility for redeposition by using strong complexing reagents [10-12], which has been reported by many groups and will not be the emphasis of this work. However, typical disadvantage of this approach is the use of corrosive and toxic chemicals, which place high demand for processing facility, safety regulation and environment policy.

- To continuously remove the dissolved metal species through combination of additional chemical / electrochemical process to promote dissolution kinetics, e.g. collecting the dissolved PGM in metallic form using electrodeposition [28].

- To block the redeposition sites to prevent or reduce redeposition process. However, such approach is often complicated to be adapted to potential transient conditions, since coverage of the active sites needs to be reversible and synchronized with the potential change; otherwise further dissolution will be limited due to surface passivation. 
Here we report a novel approach to enhance the efficiency of transient electrochemical dissolution through inhibition of the redeposition through use of surface switching species (SSS), which is capable of blocking the surface only for the potentials suitable for redeposition and opening the surface when the potential is suitable for dissolution.

Underpotential deposition of copper (Cu-UPD) on a Pt surface, a well-known phenomenon [29-35], can be utilized to block the Pt surface to prevent the redeposition through reduction of Pt-soluble species as depicted in Fig. 1b. Deposition of Pt on the Copper, although possible at lower potentials $(\mathrm{V}<0$ vs. RHE) [36], is negligible at the potentials of interest $(\mathrm{V}>0.4 \mathrm{~V})$. Again, galvanic displacement of $\mathrm{Cu}$ with $\mathrm{Pt}$, another possible mechanism for deposition of $\mathrm{Pt}$ on $\mathrm{Cu}[37,38]$ has negligible effect within the time scales of the experiment as it is a comparatively slow process.

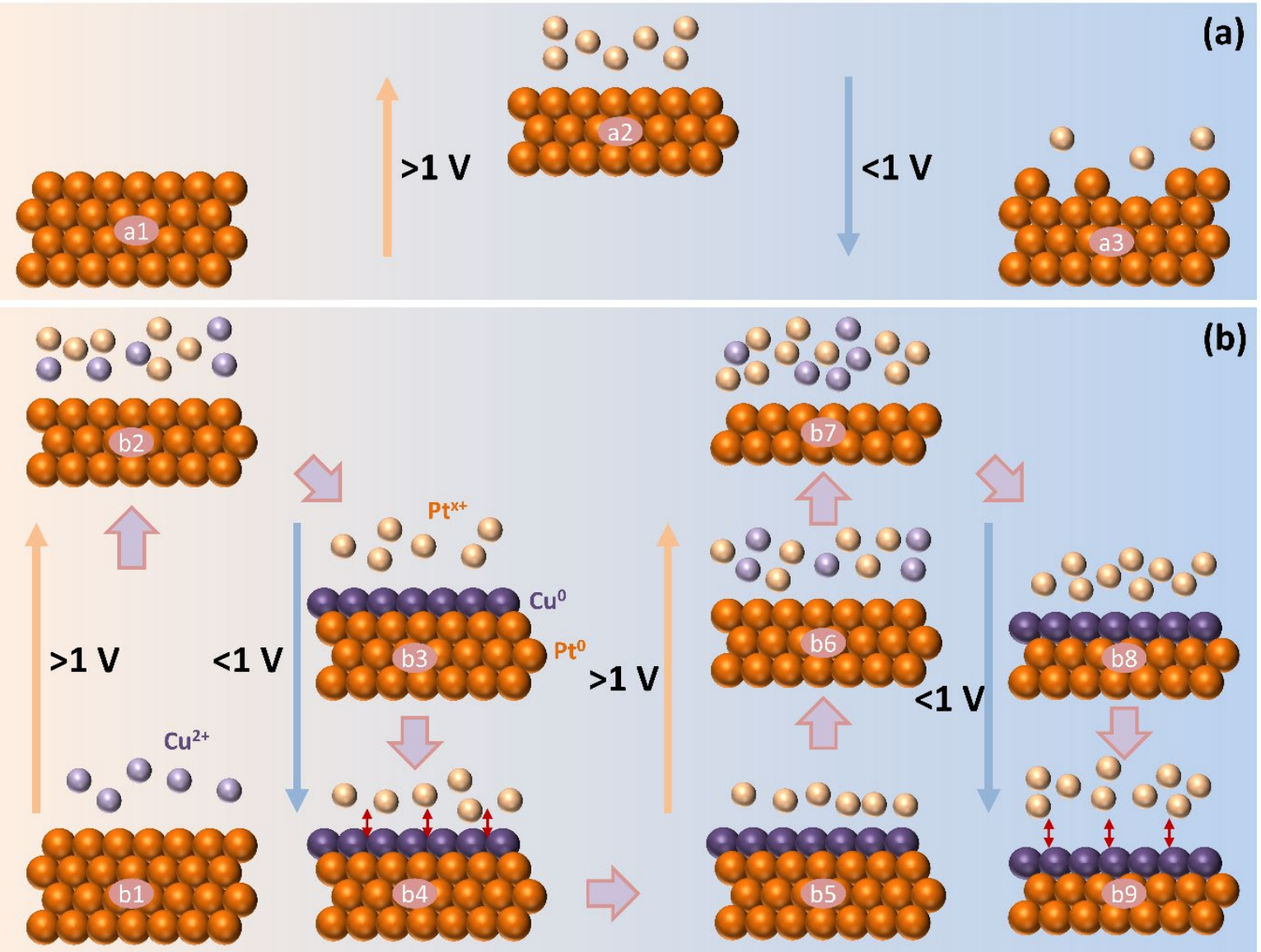


Fig. 1: Process mechanisms for dissolution of Pt through electrochemical potential cycling in (a) absence and (b) presence of $\mathrm{Cu}^{2+}$ acting as a surface switching species (SSS). For simplicity, formation and dissolution of the Pt-Oxide layer has not been depicted. In (a), redeposition of the dissolved Pt-soluble species takes place at reducing potentials during negative-going scan (a3), leading to poor overall dissolution efficiency. In presence of SSS (e.g. $\left.\mathrm{Cu}^{2+}\right)$, normal dissolution takes place during the first positive-going scan and initial part of the negativegoing scan (b1-b2). Deposition of SSS on the Pt surface takes place ideally just after the removal of the Pt-Oxide (b3, completion of dissolution cycle), to form a blocking layer on the Pt-surface for redeposition of the dissolved Pt at lower potentials (b4) of the negative-going scan of the first cycle. Positive-going scan of the second potential cycle starts with the removal of the SSS adlayer at potentials sufficiently below the standard potentials for Pt-Oxide formation (b5-b6). Dissolution of Pt takes place during the later portion of the positive-going scan and the initial part of the negative-going scan (b7), while the deposition of SSS is repeated at appropriate potential range during negative-going scan (b8-b9).

\section{Materials and Methods}

Materials: Hydrochloric acid (1 M HCl; Reagent Ph. Eur.; BDH chemicals;), nitric acid (HNO3; assay: $65 \%$, Sigma-Aldrich $\left.{ }^{\circledR}\right)$, sulfuric acid $\left(\mathrm{H}_{2} \mathrm{SO}_{4}\right.$; EMSURE $^{\circledR}$ grade, assay $>95-97 \%$, Merck, Germany), Copper(II) chloride $\left(\mathrm{CuCl}_{2} .2 \mathrm{H}_{2} \mathrm{O}\right.$; purity: $>99.99 \%$; Sigma-Aldrich $\left.\AA\right)$, Copper(II) sulfate $\left(\mathrm{CuSO}_{4} .5 \mathrm{H}_{2} \mathrm{O}\right.$; purity: $>99.99 \%$; Sigma-Aldrich $\left.{ }^{\circledR}\right)$, Copper(II) nitrate $\left(\mathrm{Cu}\left(\mathrm{NO}_{3}\right)_{2} . \mathrm{xH}_{2} \mathrm{O}\right.$; purity: $>99.99 \%$; Sigma-Aldrich $\left.{ }^{\circledR}\right)$, Sodium chloride $\left(\mathrm{NaCl}\right.$; purity: $>99.99 \%$; Sigma-Aldrich $\left.{ }^{\circledR}\right)$ were used as-received to prepare different electrolyte solutions in Milli-Q water; resistivity $\geq 18.2$ $\mathrm{M} \Omega \cdot \mathrm{cm}$ at $\left.25^{\circ} \mathrm{C}\right)$. Ammonium chloride $\left(\mathrm{NH}_{4} \mathrm{Cl}\right.$; purity: $>99.99 \%$; Sigma-Aldrich $\left.{ }^{\circledR}\right)$ and 
ammonium hexachloroplatinate $\left(\left(\mathrm{NH}_{4}\right)_{2} \mathrm{PtCl}_{6}\right.$; min. Pt: 43.4\%; Sigma-Aldrich $\left.{ }^{\circledR}\right)$ were used as received for Pt species determination and reference material.

Electrochemical studies: The electrochemical dissolution study was performed using a threeelectrode setup consisting of a working electrode (WE), a counter electrode (CE; Graphitic carbon rod; $\sim 5 \mathrm{~mm}$ diameter) and a reference electrode (RE; $\mathrm{Hg} / \mathrm{Hg}_{2} \mathrm{SO}_{4}$; $\mathrm{REF} 601$ Radiometer $\left.^{\circledR}\right)$ ). The WE, containing the Pt-nanoparticles for the dissolution study, was a $10 \mathrm{~mm}$ diameter circular disc stamped from a polymer electrolyte membrane fuel cell (PEMFC) cathode (HiSPEC $9100 \mathrm{Pt} / \mathrm{C}$ catalyst spray-coated on gas diffusion layer (GDL; BD34 SIGRACET) with a Pt loading of $\sim 0.6$ $\mathrm{mg} / \mathrm{cm}^{2}$ and an ionomer (Nafion $\left.{ }^{\circledR}\right)$ content of $\left.\sim 30 \mathrm{wt} . \%\right)$ prepared at EWII fuel cells A/S. The potentials measured w.r.t. the $\mathrm{Hg} / \mathrm{Hg}_{2} \mathrm{SO}_{4} \mathrm{RE}$ have been reported w.r.t. the reversible hydrogen electrode (RHE). Electrochemical potential cycling between specified potential range (0.4 - $1.6 \mathrm{~V}$; starting and end potential values: $1.2 \mathrm{~V}$, if otherwise not mentioned) was performed using a Zahner ${ }^{\circledR}$ IM6e electrochemical workstation in different electrolytes $(12 \mathrm{~mL}$; without gas bubbling/stirring; at room temperature and pressure).

Dissolution quantification: The Pt-loading values on WE before and after the electrochemical treatment were measured using an X-ray fluorescence spectrometer (XRF; Thermo Scientific Niton XL3t GOLDD+ XRF analyzer). The Pt-loading values were used to estimate the dissolution $\%$ of Pt (eq. 1). Calibration of Pt loading using XRF is described in our previous work [22]. The \%dissolution, was calculated using the following equation-

$\%$ dissolution $=\frac{W_{0}-W_{f}}{W_{0}} \times 100$ where $W_{0}$ and $W_{f}$ are respectively the initial and final Pt-loadings on the electrode. Again, atomic absorption spectroscopy (AAS; Graphite Furnace Agilent 200 Series AA analyzer) was used to determine the amount of dissolved Pt in the electrolyte after the dissolution study. As 
shown in table S1, the dissolution \% of Pt calculated using both the methods (XRF and AAS) were in good agreement even for large variations of \%dissolution values. This evidence also indicates, in the conditions studied, platinum dissolution is the major degradation mechanism among other possible reactions of $\mathrm{Pt} / \mathrm{C}$ degradation [39]. Despite an anodic corrosion of carbon is known to occur at $E>+0.8 \mathrm{~V}_{\mathrm{RHE}}$ [40], its contribution is negligible under the current study.

Evolution of the Pt concentration in electrolyte with the electrode potential during potential cycling was examined by examining The Pt concentration in the electrolyte at different potentials during an electrochemical potential cycle (start: $1.2 \mathrm{~V}$; upper potential: $1.6 \mathrm{~V}$; lower potential: $0.4 \mathrm{~V}$; end potential: $1.6 \mathrm{~V}$ ). For the Pt concentration determination through AAS, the electrolyte samples (100 $\mu \mathrm{L})$ were collected after each $0.2 \mathrm{~V}$, starting from $1.2 \mathrm{~V}$. A comparatively slow scan rate $(10 \mathrm{mV} / \mathrm{s})$ was used to enable the sample collection at a certain potential. Again, fast distribution of the dissolved Pt species in the electrolyte was ensured through magnetic stirring (RPM; 1000). For measurements with no initial Pt concentration in the electrolyte, samples were collected during a potential cycle in a fresh electrolyte. In other cases, to study the effect of accumulated Pt species in electrolyte, the electrode was subjected to 5 dissolution potential cycles $(0.4-1.6 \mathrm{~V} ; 100 \mathrm{mV} / \mathrm{s})$ before the measurement potential cycle $(0.4-1.6 \mathrm{~V} ; 10 \mathrm{mV} / \mathrm{s}$, start point; $1.2 \mathrm{~V})$.

Structural characterizations: The change in average crystallite size $(L)$ of the Pt-nanoparticles was estimated through X-ray diffraction (XRD) using a Rigaku Miniflex 600 X-ray diffractometer (X-ray radiation: $\mathrm{Cu} \mathrm{K \alpha}(\lambda=1.5418 \AA))$. X-ray diffraction peak corresponding to $\mathrm{Pt}(111)$ at diffraction angle $(2 \theta)=39.8^{\circ}$ (JCPDS\# 65-2868) [41] was used to determine $L$ using Scherer's formula $(L=0.9 \lambda / \beta \operatorname{Cos} \theta$; where $\beta$ is the full width at half maximum (FWHM; $2 \Delta \theta)$ of the diffraction peak). The FWHM was determined by fitting the peak using Lorentz distribution. 
Again, transmission electron microscope (TEM) imaging using a JEOL JEM-2100 TEM operated at $100 \mathrm{kV}$ was employed to observe the change in average particle size of the nanoparticles. X-ray photoelectron spectroscopy (XPS) was performed to confirm the formation/removal of Cu-adlayer on the Pt-nanoparticles. The XPS analysis was performed using a SPECS ${ }^{\circledR}$ system. The spectrometer was equipped with a hemispherical analyzer and a monochromator. The XPS data were acquired using $\mathrm{Mg} \mathrm{Ka}(1253.6 \mathrm{eV})$ radiation. The binding energies of the $\mathrm{C} 1 \mathrm{~s}, \mathrm{O} 1 \mathrm{~s}, \mathrm{~F} 1 \mathrm{~s}$, and Pt $4 \mathrm{f}$ of the samples were calibrated with respect to C 1s: graphitized carbon peak at $284.5 \mathrm{eV}$. Survey spectra were collected at pass energy of $50 \mathrm{eV}$, resolution $2.5 \mathrm{eV}$ over the binding energy range $0-1250 \mathrm{eV}$. Selected area electron diffraction, High-resolution TEM (HRTEM) in combination with electron energy loss spectroscopy (EELS) and scanning transmission electron microscopy (STEM) in combination with energy dispersive spectroscopy (EDS) was performed by using a JEOL 3000F operated at $300 \mathrm{kV}$ and equipped with a GIF2000 spectrometer and an Oxford instruments EDS detector. The HRTEM images were analyzed with fast Fourier transform (FFT) and inverse FFT (IFFT) methods using digital micrograph software (Gatan). The IFFT images of individual nanoparticles were produced after masking the FFT image excluding the strong diffraction spots, as shown in Fig. S4.

Further, UV-vis spectroscopy (Perkin Elmer; Lambda 900 UV/VIS/NIR spectrometer) was employed to determine the oxidation state of the Pt species dissolved during electrochemical treatment. The UV/Vis spectra were recorded using a reference electrolyte of identical concentrations of all the species other than the Pt species. In addition to oxidation state investigation through the UV-vis spectroscopy, the $\mathrm{Pt}^{2+} / \mathrm{Pt}^{4+}$ molar ratio of the electrochemically dissolved $\mathrm{Pt}$ was also determined by precipitating the $\mathrm{Pt}^{4+}$ species present in the post-dissolution electrolyte of a known $\mathrm{Pt}$ concentration $\left(\mathrm{C}^{i}\right)$ in form of $\left(\mathrm{NH}_{4}\right)_{2} \mathrm{PtCl}_{6}$ through addition of $\mathrm{NH}_{4} \mathrm{Cl}$ powder to a concentration of $2 \mathrm{M}$ followed by centrifugal separation after overnight aging. Comparable values 
of $C^{i}$ for the $0.1 \mathrm{M} \mathrm{HCl}$ and the $0.1 \mathrm{M} \mathrm{HCl}+0.01 \mathrm{M} \mathrm{CuCl}_{2}$ electrolytes are achieved by potential cyclic (650 cycles; 0.4-1.6V, $100 \mathrm{mV} / \mathrm{s})$ dissolution of Pt from the PEMFC electrodes $(6.3 \times 12.5$ $\mathrm{cm}^{2}$ GDL separated from a spent PEMFC MEA from EWII fuel cell A/S) with average Pt loadings of $\sim 0.4$ and $0.2 \mathrm{mg} / \mathrm{cm}^{2}$, respectively.

The resultant yellow precipitation was separated by centrifuging and the concentration of Pt in supernatant $\left(C^{f}\right)$ was determined by AAS. Assuming $\mathrm{Pt}^{2+}$ and $\mathrm{Pt}^{4+}$ are the only oxidation states of Pt present in the solution, the concentration of $\mathrm{Pt}^{2+}\left(C^{P t 2+}\right)$ was calculated using the relation$C^{P t 2+}=\left(C^{f}-C^{d}\right)$, with $C^{d}$ being the solubility of $\left(\mathrm{NH}_{4}\right)_{2} \mathrm{PtCl}_{6}$ in the corresponding electrolyte $\left(0.1 \mathrm{M} \mathrm{HCl}\right.$ or $\left.0.1 \mathrm{M} \mathrm{HCl}+0.01 \mathrm{M} \mathrm{CuCl}_{2}\right)$ containing $1 \mathrm{M} \mathrm{NH} 4 \mathrm{Cl}$, as determined by preparing saturated $\left(\mathrm{NH}_{4}\right)_{2} \mathrm{PtCl}_{6}$-solution in the electrolyte and measuring the Pt concentration through AAS. Similarly, the concentration of $\mathrm{Pt}^{4+}\left(C^{P t 4+}\right)$ was estimated using the relation- $C^{P t 4+}=\left(C^{i}-\right.$ $\left.C^{P t 2+}\right)$. The precipitated $\left(\mathrm{NH}_{4}\right)_{2} \mathrm{PtCl}_{6}$ was characterized through $\mathrm{XRD}$ after purification through ethanol washing and drying.

\section{Results and discussion}

Evolution of physical state of electrodes during dissolution: Evolution of the average crystallite size of Pt-nanoparticles during potential cycling in $\mathrm{Cl}^{-}$containing dilute acidic baths has been revealed by the XRD patterns of Fig. 2a. The decreased Pt (hkl) peak widths for the electrochemically treated electrodes (50 potential cycles between 0.4 and $1.6 \mathrm{~V}$ at a scan rate of 100 $\mathrm{mV} / \mathrm{s}$ in $0.1 \mathrm{M} \mathrm{HCl}$ or $0.1 \mathrm{M} \mathrm{HCl}+0.2 \mathrm{M} \mathrm{NaCl}$ ) as compared to that for a pristine sample suggest significant growth of crystallite size during the electrochemical potential cycling. Consistent increase of crystallite size even for \%dissolution extents as high as $75 \%$ suggests redeposition of dissolved Pt on the source nanoparticles. In addition, with increasing \%dissolution, the ratio between the $\%$ growth (defined as the $\%$ change of crystalline size w.r.t. that of the pristine 
electrode) and the \%dissolution increases (Fig. 2b) due to increased concentration of dissolved Pt leading to higher rates of redeposition.

Cyclic voltammograms of a typical $\mathrm{Pt} / \mathrm{C}$ WE used in the present study recorded in $0.1 \mathrm{M} \mathrm{HCl}$ and $0.1 \mathrm{M} \mathrm{HCl}+0.01 \mathrm{M} \mathrm{CuCl}_{2}$ at a scan rate of $10 \mathrm{mV} / \mathrm{s}$ are shown in Fig. 2c. (The corresponding cyclic voltammograms recorded at a scan rate of $100 \mathrm{mV} / \mathrm{s}$, the actual scan rate used for the electrochemical dissolution study, are provided in Fig. S1 (supplementary information S1). The cyclic voltammograms document the suitability of $\mathrm{Cu}^{2+}$ as SSS for inhibition of redeposition during electrochemical potential cycling. Cu-UPD on the Pt surface during the negative-going scan takes place over a wide potential range below $\sim 0.9 \mathrm{~V}$ with no sharp current peak; while a Cu-stripping peak during the positive-going scan appears between $\sim 0.5$ and $\sim 0.8 \mathrm{~V}$. Further, large current for potentials above $\sim 1.4 \mathrm{~V}$ during positive-going scan may be attributed to $\mathrm{Cl}_{2}$ evolution through $\mathrm{Cl}_{2}+2 e^{-} \rightarrow 2 \mathrm{Cl}^{-}(1.358 \mathrm{~V})$, while that for potentials $>1.3 \mathrm{~V}$ during negative-going scan corresponds to the reduction of $\mathrm{Cl}_{2}$ [42]. Formation and removal of the $\mathrm{Cu}$-adlayer on the $\mathrm{Pt} / \mathrm{C}$ electrode during the negative-going and positive-going scans can be confirmed further through Xray photoelectron spectroscopy (XPS). XPS spectra of pristine and electrochemically treated electrodes have been shown in Fig. 2d. The electrochemical treatment involved potential cycling between 0.4 and $1.6 \mathrm{~V}$ at a scan rate of $100 \mathrm{mV} / \mathrm{s}$ for 2 cycles in $0.1 \mathrm{M} \mathrm{HCl}+0.01 \mathrm{M} \mathrm{CuCl}_{2}$ with the end potentials for cycling being $0.4 \mathrm{~V}$ (negative-going scan) and $0.8 \mathrm{~V}$ (positive-going scan) for the $\mathrm{Cu}-0.4-\mathrm{F}$ and $\mathrm{Cu}-0.8-\mathrm{R}$ electrodes, respectively (Fig. S2; supplementary information S1). The presence of $\mathrm{Cu} 2 \mathrm{p}$ peaks in the XPS spectrum of the $\mathrm{Cu}-0.4-\mathrm{F}$ electrode suggest the deposition of $\mathrm{Cu}$ during the negative-going scan to $0.4 \mathrm{~V}$. Further, for the $\mathrm{Cu}-0.8$ - $\mathrm{R}$ electrode, the relatively lower intensities of the $\mathrm{Cu} 2 \mathrm{p}$ peaks may be attributed to the partial stripping of $\mathrm{Cu}$ during the positive-going scan between 0.4 and $0.8 \mathrm{~V}$. With further increase of the potential during positivegoing scan, completion of the $\mathrm{Cu}$ stripping leads to the Pt surface being exposed to the electrolyte 
completely. Hence, with presence of $\mathrm{Cu}^{2+}$, the Pt surface is exposed to the electrolyte for the oxidizing potentials and remains inaccessible, at least partially to the electrolytes for reducing potentials.
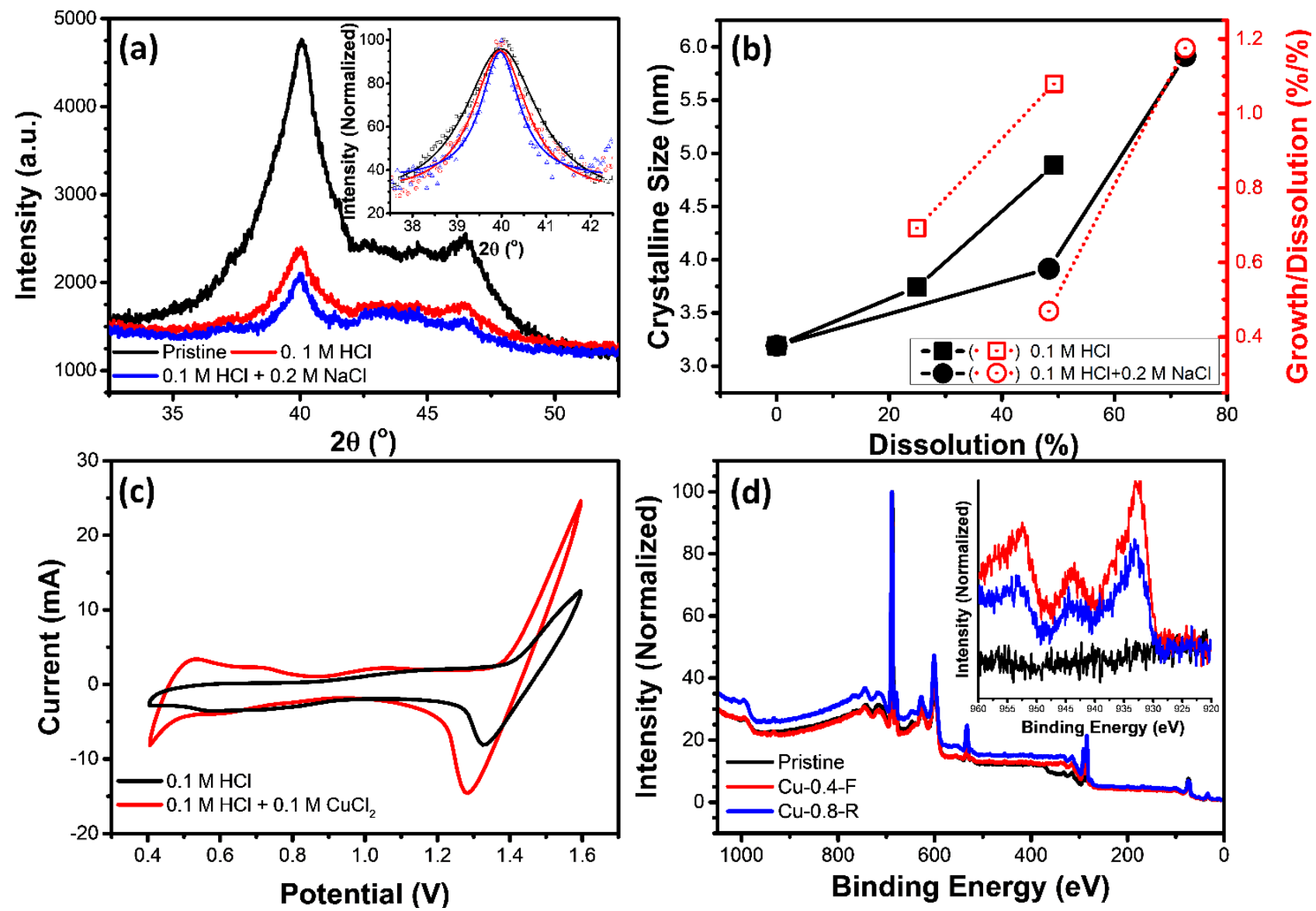

Fig. 2: (a) XRD patterns of the pristine and electrochemically treated $\mathrm{Pt} / \mathrm{C}$ electrodes. Inset shows the intensity normalized Pt (111) diffraction peaks revealing the effect of electrochemical treatment of the peak width (FWHM). (b) Variations of the Pt-crystallite size calculated using Scherer formula for Pt (111) XRD peak with the \%dissolution during electrochemical potential cycling for 25 and 50 cycles in different electrolytes. (c) Cyclic voltammograms of $\mathrm{Pt} / \mathrm{C}$ electrodes in different electrolytes at a scan rate of $100 \mathrm{mV} / \mathrm{s}$. (d) XPS spectra of pristine and electrochemically treated Pt/C electrodes (Inset: Magnified Cu-2p peaks). 
Chemical state of dissolved Pt species: $\mathrm{Pt}$ dissolution in $\mathrm{Cl}^{-}$-free electrolytes takes place preferentially through $\mathrm{Pt}^{2+}$ formation $[43,44]$. On the other hand, dissolution of $\mathrm{Pt}$ in presence of $\mathrm{Cl}^{-}$ takes place by the formation of $\left[\mathrm{PtCl}_{4}\right]^{2-}$ or $\left[\mathrm{PtCl}_{6}\right]^{2-}$ complexes through equations (2) and (3) [42, $45]$, and possibly followed by the oxidation of $\left[\mathrm{PtCl}_{4}\right]^{2-}$ to $\left[\mathrm{PtCl}_{6}\right]^{2-}$ at higher potentials during potential cycling through eq. (4).

$$
\begin{aligned}
& {\left[\mathrm{PtCl}_{4}\right]^{2-}+2 e^{-} \rightarrow \mathrm{Pt}+4 \mathrm{Cl}^{-}\left(E^{o}=0.75 \mathrm{~V}\right)} \\
& {\left[\mathrm{PtCl}_{6}\right]^{2-}+4 e^{-} \rightarrow \mathrm{Pt}+6 \mathrm{Cl}^{-}\left(E^{o}=0.742 \mathrm{~V}\right)} \\
& {\left[\mathrm{PtCl}_{6}\right]^{2-}+2 e^{-} \rightarrow\left[\mathrm{PtCl}_{4}\right]^{2-}+2 \mathrm{Cl}^{-}\left(E^{o}=0.68 \mathrm{~V}\right)}
\end{aligned}
$$

However, there may be different redox reactions involving $\mathrm{Cu}^{2+}$ and leading to an unusual $\mathrm{Pt} 2+/ \mathrm{Pt} 4+$ ratio. To investigate such possibility, chemical state of the dissolved Pt species was examined by spectroscopic and solution chemistry methods.

Fig. 3 shows the UV-Vis spectra of various electrolytes containing electrochemically dissolved Pt species. For the electrolytes containing dissolved Pt species (irrespective to the presence/absence of $\mathrm{Cu}^{2+}$ ) presence of the absorbance peak centered at $260 \mathrm{~nm}$ (Fig. 3a) suggests the presence of $\left[\mathrm{PtCl}_{6}\right]^{2-}$ complex, which corresponds to the $\mathrm{Pt}^{4+}$ oxidation state. A comparison of the UV-vis spectra of the $\left[\mathrm{PtCl}_{6}\right]^{2-}$ and $\left[\mathrm{PtCl}_{4}\right]^{2-}$ complexes in $0.1 \mathrm{M} \mathrm{HCl}$ has been shown in Fig. 3b. The absence of absorption peak corresponding to $\mathrm{Pt}^{2+}$ for both the cases (presence/absence of $\mathrm{Cu}^{2+}$ ) indicates that $\mathrm{Cu}$ has no effect on the oxidation state of the dissolved $\mathrm{Pt}$ species $\left(\mathrm{Pt}^{4+}\right.$ for both the cases). However, although the UV-vis spectra are measured using the relevant electrolyte as the reference to eliminate the absorption signal from the electrolyte, high absorbance of $\mathrm{Cu}^{2+}$ at wavelengths below $300 \mathrm{~nm}$ (Fig. 3d), might affect the measurement sensitivity making it inadequate to observe the low concentrations of $\mathrm{Pt}^{2+}$. 

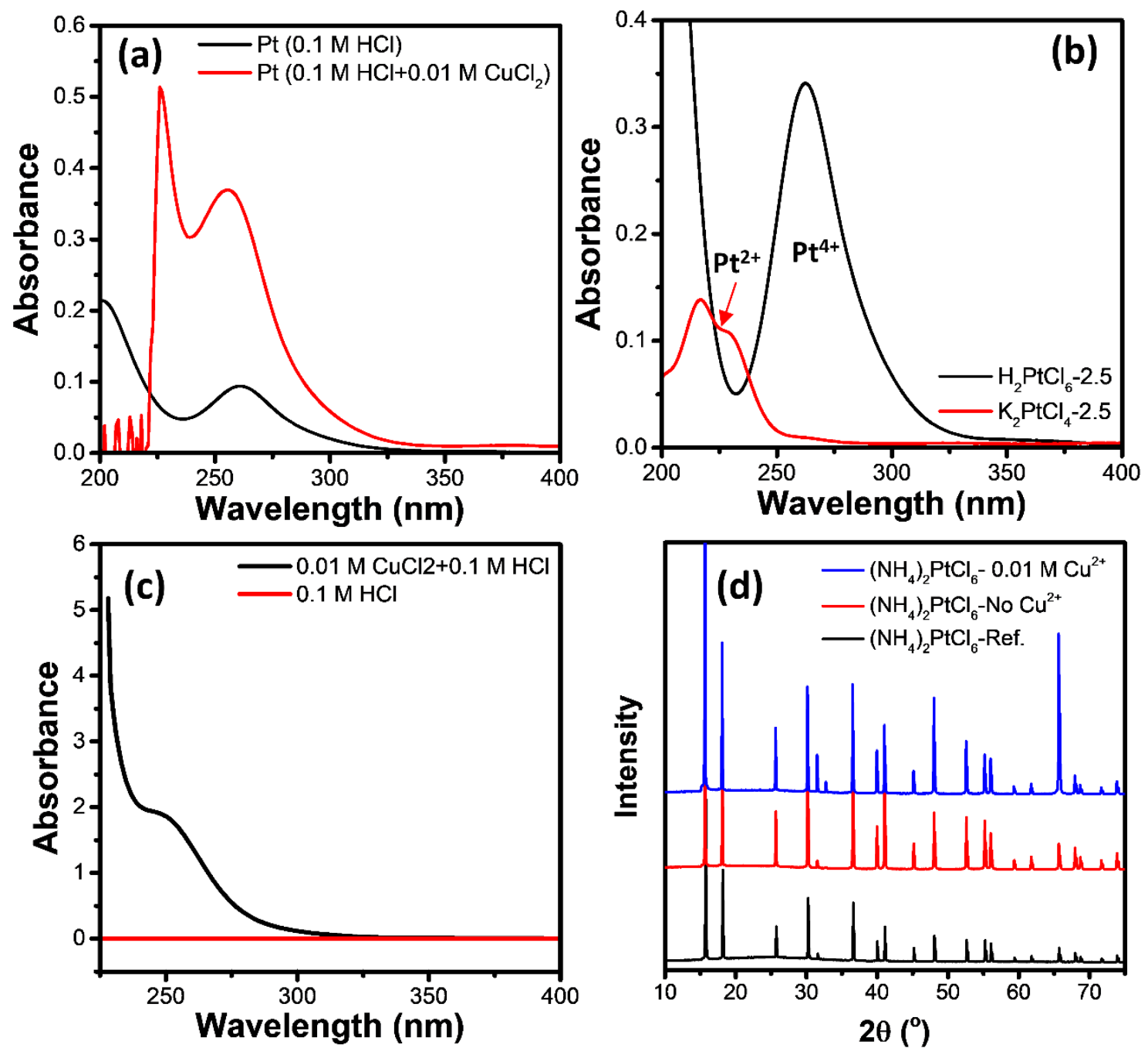

Fig. 3: UV-Vis spectra of (a) the electrolytes containing Pt species from electrochemically dissolved Pt with Pt concentrations of 2.7 and $6.7 \mu \mathrm{M}$ respectively for $\mathrm{Pt}(0.1 \mathrm{M} \mathrm{HCl})$ and $\mathrm{Pt}(0.1 \mathrm{M} \mathrm{HCl}-0.01$ $\mathrm{M} \mathrm{CuCl}_{2}$ ), (b) the commercial Pt precursors, namely $\mathrm{H}_{2} \mathrm{PtCl}_{6}$ and $\mathrm{K}_{2} \mathrm{PtCl}_{4}$ solutions in $0.1 \mathrm{M} \mathrm{HCl}$ having equal Pt concentrations of $12.8 \mu \mathrm{M}$ and (c) the electrolytes, namely $0.1 \mathrm{M} \mathrm{HCl}$ and $0.1 \mathrm{M}$ $\mathrm{HCl}+0.01 \mathrm{M} \mathrm{CuCl}_{2}$ used in the study. The spectra (a) and (b) are recorded using the respective electrolytes as reference, while milliQ-water is used as reference for (c). (d) XRD patterns of the precipitated $\left(\mathrm{NH}_{4}\right)_{2} \mathrm{PtCl}_{6}$ samples corresponding to $\mathrm{Pt}$ dissolution studies in $0.1 \mathrm{M} \mathrm{HCl}$ $\left(\left(\mathrm{NH}_{4}\right)_{2} \mathrm{PtCl}_{6}-\mathrm{No} \mathrm{Cu}^{2+}\right)$ and $0.1 \mathrm{M} \mathrm{HCl}+0.01 \mathrm{M} \mathrm{CuCl}_{2}\left(\left(\mathrm{NH}_{4}\right)_{2} \mathrm{PtCl}_{6}-0.01 \mathrm{M} \mathrm{Cu}^{2+}\right)$ electrolytes. For reference, XRD pattern of the commercial $\left(\mathrm{NH}_{4}\right)_{2} \mathrm{PtCl}_{6}\left(\left(\left(\mathrm{NH}_{4}\right)_{2} \mathrm{PtCl}_{6}-\mathrm{Ref}\right.\right.$.) is also shown. 
Therefore, another method based on classical Pt chemistry has been employed to determine the $\mathrm{Pt}^{2+} / \mathrm{Pt}^{4+}$ molar ratio. Hydrometallurgical PGM extraction methods employ precipitation of the $\mathrm{Pt}$ dissolved in chloride-containing electrolytes in form of the $\left(\mathrm{NH}_{4}\right)_{2} \mathrm{PtCl}_{6}$ salt [17], utilizing its very low solubility in aqueous $\mathrm{NH}_{4} \mathrm{Cl}$ solution (Table 1). Here, we demonstrate that irrespective of the presence/absence of $\mathrm{Cu}^{2+}$ during potential cycling, the electrochemically dissolved Pt can be precipitated in form of $\left(\mathrm{NH}_{4}\right)_{2} \mathrm{PtCl}_{6}$. As shown in table $1, \mathrm{Pt}^{2+} / \mathrm{Pt}^{4+}$ ratios for electrochemical dissolution in either of the electrolytes $\left(0.1 \mathrm{M} \mathrm{HCl}\right.$ or $\left.0.1 \mathrm{M} \mathrm{HCl}+0.01 \mathrm{M} \mathrm{CuCl}_{2}\right)$ remain quite low $\left(\mathrm{Pt}^{2+} / \mathrm{Pt}^{4+}\right.$ ratio 0.00 for $0.1 \mathrm{M} \mathrm{HCl}$ and 0.02 for $0.1 \mathrm{M} \mathrm{HCl}+0.01 \mathrm{M} \mathrm{CuCl}_{2}$; with the difference being within the statistical error) suggesting majority of the dissolved $\mathrm{Pt}$ in form of $\left[\mathrm{PtCl}_{6}\right]^{2-}$ complex. XRD patterns of the precipitated $\left(\mathrm{NH}_{4}\right)_{2} \mathrm{PtCl}_{6}$ samples from both the electrolytes show the characteristic $\left(\mathrm{NH}_{4}\right)_{2} \mathrm{PtCl}_{6}$ diffraction pattern [46] (expect for an extra peak at $\sim 32.7^{\circ}$, corresponding to the most intense diffraction peak from $\mathrm{NH}_{4} \mathrm{Cl}$; JCPDS 73-0365), confirming no effect of presence of $\mathrm{Cu}^{2+}$ on the nature of the precipitation (Fig. 3d). Hence, during electrochemical dissolution in presence of $\mathrm{Cl}^{-}$, the $\left[\mathrm{PtCl}_{4}\right]^{2-}$ species are either not formed or oxidized spontaneously to the more stable $\left[\mathrm{PtCl}_{6}\right]^{2-}$ species. Further, presence of $\mathrm{Cu}^{2+}$ has insignificant effect on the nature of the redox reactions responsible for the Pt dissolution.

Table 1: $\mathrm{Pt}^{2+} \mathrm{Pt}^{4+}$ ratio of the Pt dissolved electrochemically in $0.1 \mathrm{M} \mathrm{HCl}$ or $0.1 \mathrm{M} \mathrm{HCl}+0.01 \mathrm{M}$ $\mathrm{CuCl}_{2}$

\begin{tabular}{|c|c|c|c|c|c|c|}
\hline Electrolyte & $\begin{array}{l}\text { Initial Pt } \\
\text { conc. } \\
(\mu \mathrm{M})\end{array}$ & $\begin{array}{l}\text { Extract Pt } \\
\text { conc. } \\
(\mu \mathrm{M})\end{array}$ & $\begin{array}{l}\left(\mathrm{NH}_{4}\right)_{2} \mathrm{PtCl}_{6} \\
\text { solubility } \\
(\mu \mathrm{M})\end{array}$ & $\begin{array}{l}\mathrm{Pt}^{2+} \\
\text { conc. } \\
(\mu \mathrm{M})\end{array}$ & $\begin{array}{l}\mathrm{Pt}^{4+} \\
\text { conc. } \\
(\mu \mathrm{M})\end{array}$ & $\begin{array}{l}\mathrm{Pt}^{2+} / \mathrm{Pt}^{4+} \\
\text { ratio }\end{array}$ \\
\hline $0.1 \mathrm{M} \mathrm{HCl}$ & 884 & 82 & 82 & 0 & 884 & 0.00 \\
\hline $\begin{array}{l}0.1 \mathrm{M} \mathrm{HCl}+0.01 \mathrm{M} \\
\mathrm{CuCl}_{2}\end{array}$ & 722 & 58 & 42 & 16 & 706 & 0.02 \\
\hline
\end{tabular}

\section{Pt concentration evolution with potential/time during potentiodynamic treatment: Fig. 4} shows the effect of presence of SSS on the redeposition of dissolved Pt species $\left(\mathrm{Pt}^{4+}\right.$ in both 
presence/absence of $\mathrm{Cu}^{2+}$ ). Evolution of the Pt concentrations in electrolyte with the electrode potential during potential cycling $(0.1 \mathrm{M} \mathrm{HCl}, 10 \mathrm{mV} / \mathrm{s})$ shows significant difference in presence/absence of $\mathrm{Cu}^{2+}$ as the SSS. In $0.1 \mathrm{M} \mathrm{HCl}$ electrolyte, for initial cycle (no soluble Pt species already present in the electrolyte, Fig. 4a black) the Pt concentration builds up during negative-going scan $(\mathrm{E}<1.0 \mathrm{~V})$, which may be explained by mechanism of place exchange of oxygen atoms from surface to sub-surface positions during reduction [47]. The Pt concentration decreases marginally during the positive-going scan for potentials $<1.0 \mathrm{~V}$ before a sharp increase for potentials $>1.0 \mathrm{~V}$ (thermodynamic potential for platinum oxidation). The marginal decrease of the concentration (Inset: Fig. 4a) during the subsequent positive-going scan may be attributed to the redeposition of the dissolved Pt species on the Pt nanoparticles through adsorption of the $\left[\mathrm{PtCl}_{6}\right]^{2-}$ species on fresh (oxide-free) Pt surface [48]. The redeposition becomes even clearer when a higher concentration of dissolved Pt species is present in the electrolyte. The concentration of dissolved Pt species is increased by applying a potential cycling treatment of 5 stress cycles $(0.4-1.6 \mathrm{~V} ; 100$ $\mathrm{mV} / \mathrm{s})$ to the electrode before the concentration measurement cycle $(0.4-1.6 \mathrm{~V} ; 10 \mathrm{mV} / \mathrm{s})$. Potential/time plot for the overall electrochemical treatment of the electrode for the Pt concentration vs. potential measurements is shown in Fig. S3 (supplementary information S1). As shown, the Pt concentration vs. potential profile shows a significant reduction of Pt concentration in $0.1 \mathrm{M} \mathrm{HCl}$ electrolyte during positive-going scan for potentials $<1.0 \mathrm{~V}$ (Fig. $4 \mathrm{a}$, red) while no such Pt concentration reduction is observed for the electrolyte containing $\mathrm{Cu}^{2+}$ as the SSS (Fig. 4b, red). The observations can also be made through the Pt concentration/time plots of Fig $3 \mathrm{c}$ and Fig. $4 \mathrm{~d}$ corresponding respectively to the $0.1 \mathrm{M} \mathrm{HCl}$ and the $0.1 \mathrm{M} \mathrm{HCl}+0.01 \mathrm{M} \mathrm{CuCl}_{2}$ electrolytes. As can be seen, plots labeled with 0 and 5 stress cycles correspond to different initial $(t=0 \mathrm{~s})$ concentrations of Pt species in electrolytes. The Pt concentrations corresponding to both the conditions ( 0 and 5 stress cycles) increase consistently for $0.1 \mathrm{M} \mathrm{HCl}+0.01 \mathrm{M} \mathrm{CuCl}_{2}$, while for 0.1 
$\mathrm{M} \mathrm{HCl}$, a drop in Pt concentration is observed around $\mathrm{t}=175 \mathrm{~s}$ due to redeposition of the dissolved Pt. This confirms the proposed mechanism of increased Pt \%dissolution in presence of SSS.
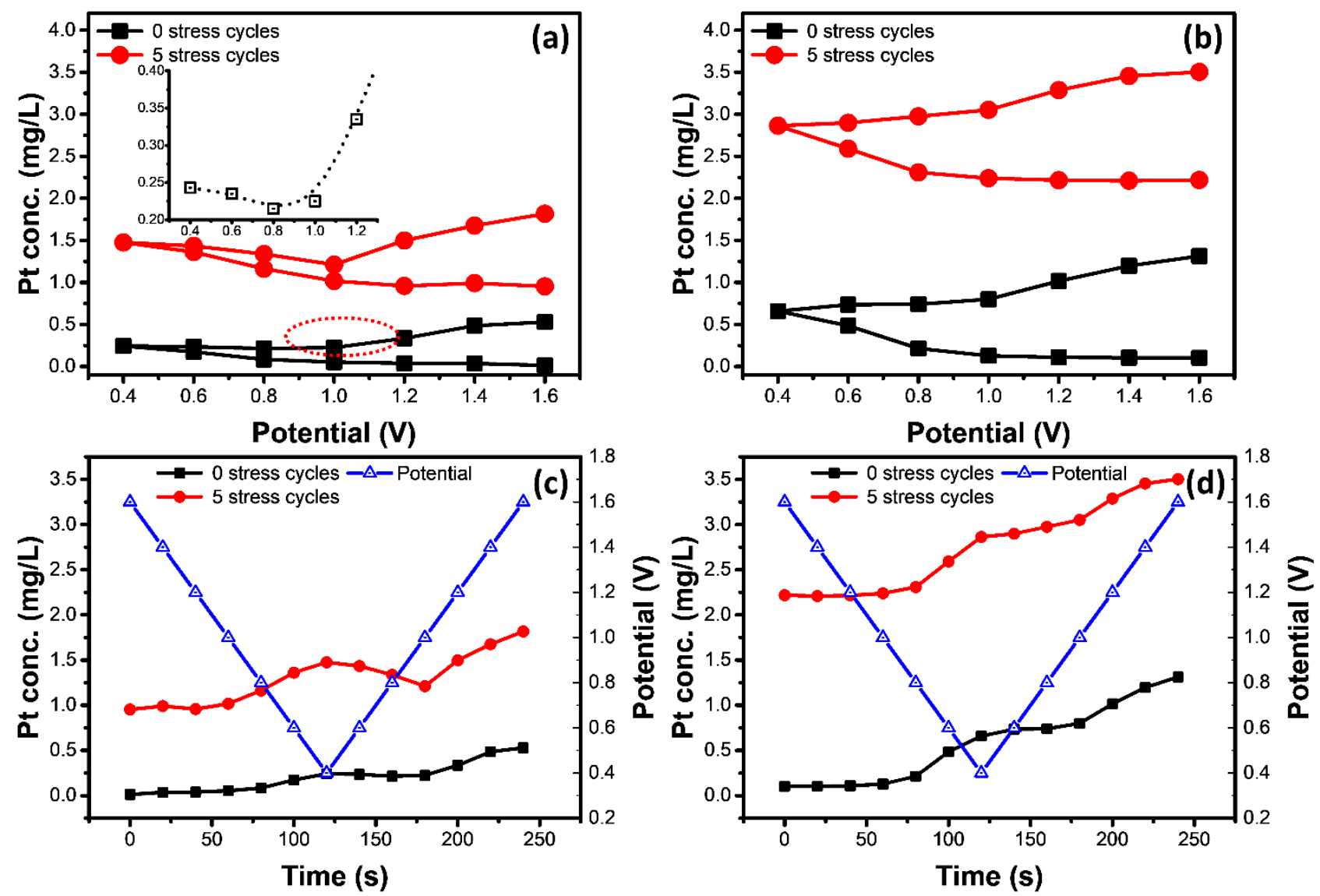

Fig. 4: Variations of the Pt concentrations in (a) $0.1 \mathrm{M} \mathrm{HCl}$ and (b) $0.1 \mathrm{M} \mathrm{HCl}+0.01 \mathrm{M} \mathrm{CuCl}_{2}$ electrolytes with the potentials during potentiodynamic dissolution of Pt. The inset of (a) shows a magnified view of the encircled concentration evolution curve during positive-going scan. Variations of the Pt concentrations with the treatment time during potentiodynamic dissolution of Pt in (c) $0.1 \mathrm{M} \mathrm{HCl}$ and (d) $0.1 \mathrm{M} \mathrm{HCl}+0.01 \mathrm{M} \mathrm{CuCl}_{2}$. Plots labeled with 0 and 5 stress cycles correspond to different initial concentrations of Pt species in electrolytes.

Further, as the Pt recovery through potential cycling may prove energy inefficient due to low Coulombic efficiency (moles of Pt dissolved/charge), the impact of presence of $\mathrm{Cu}$ on the energy 
efficiency of the dissolution process has been calculated. Here, the effect of presence of $\mathrm{Cu}^{2+}$ on the efficiency is studied by measuring the corresponding voltammogram areas (current $\times$ time) and hence the total charge $(\mathrm{C})$ values for the first potential cycles in $0.1 \mathrm{M} \mathrm{HCl}$ and $0.1 \mathrm{M} \mathrm{HCl}+0.01 \mathrm{M}$ $\mathrm{CuCl}_{2}$ electrolytes recorded at a scan rate of $10 \mathrm{mV} / \mathrm{s}$. Table 2 shows the effect of presence of $\mathrm{Cu}^{2+}$ on the Coulombic efficiencies, where the corresponding Pt concentrations after the first cycle are taken from Fig. 4. As compared to that for $0.1 \mathrm{M} \mathrm{HCl}$, the Coulombic efficiency of Pt dissolution for the $0.1 \mathrm{M} \mathrm{HCl}+0.01 \mathrm{M} \mathrm{CuCl}_{2}$ electrolyte shows an increase of $\sim 71 \%$., suggesting significant improvement due to presence of the $\mathrm{Cu}^{2+}$ as SSS.

Table 2: Effect of presence of $\mathrm{Cu}^{2+}$ on Coulombic efficiencies of the potentiodynamic Pt dissolution

\begin{tabular}{|l|l|l|l|}
\hline Electrolyte & $\begin{array}{l}\text { Dissolved Pt } \\
\text { concentration }(\mu \mathrm{M})\end{array}$ & $\begin{array}{l}\text { Voltammogram } \\
\text { area }(\mathrm{C})\end{array}$ & $\begin{array}{l}\text { Coulombic efficiency } \\
(\mu \mathrm{M} / \mathrm{C})\end{array}$ \\
\hline $0.1 \mathrm{M} \mathrm{HCl}$ & 2.7 & 0.48 & 5.6 \\
\hline $0.1 \mathrm{M} \mathrm{HCl}+0.01 \mathrm{M} \mathrm{CuCl}_{2}$ & 6.7 & 0.70 & 9.6 \\
\hline
\end{tabular}

Structural characteristics of the electrodes: A HRTEM image of Pt/C catalyst from the electrode subjected to a negative-going scan to $0.4 \mathrm{~V}$ is shown in Fig. 5a. Owing to their similar crystal structure (FCC) and lattice constants (Cu: $3.6 \AA$; Pt: $3.9 \AA)$, identification of lattice fringes corresponding to $\mathrm{Cu}$ or Pt-Cu alloy is difficult. The inverse fast Fourier transform (IFFT, obtained as shown in Fig. S5; supplementary information) image (Fig. 5b) of a Pt-nanoparticle (indicated in Fig. 5a by a rectangle) reveals bending of lattice fringes near the particle edge, possibly due to relaxation of the surface atoms. Further, EELS analysis of the same sample (Fig. 5c) confirms the presence of a weak edge at $\sim 931 \mathrm{eV}$ corresponding to the $\mathrm{Cu}-\mathrm{L}_{3}$ edge [49]. Also, the $\mathrm{Cu}-\mathrm{L}_{3}$ edge has been observed only in vicinity of the Pt surface and not on a carbon surface, which indicated the 
preferential deposition of $\mathrm{Cu}$ on Pt. Hence, the HRTEM analysis confirms the presence of $\mathrm{Cu}$ either in form of $\mathrm{Cu}$ or Pt-Cu alloy deposition on the Pt-nanoparticles.
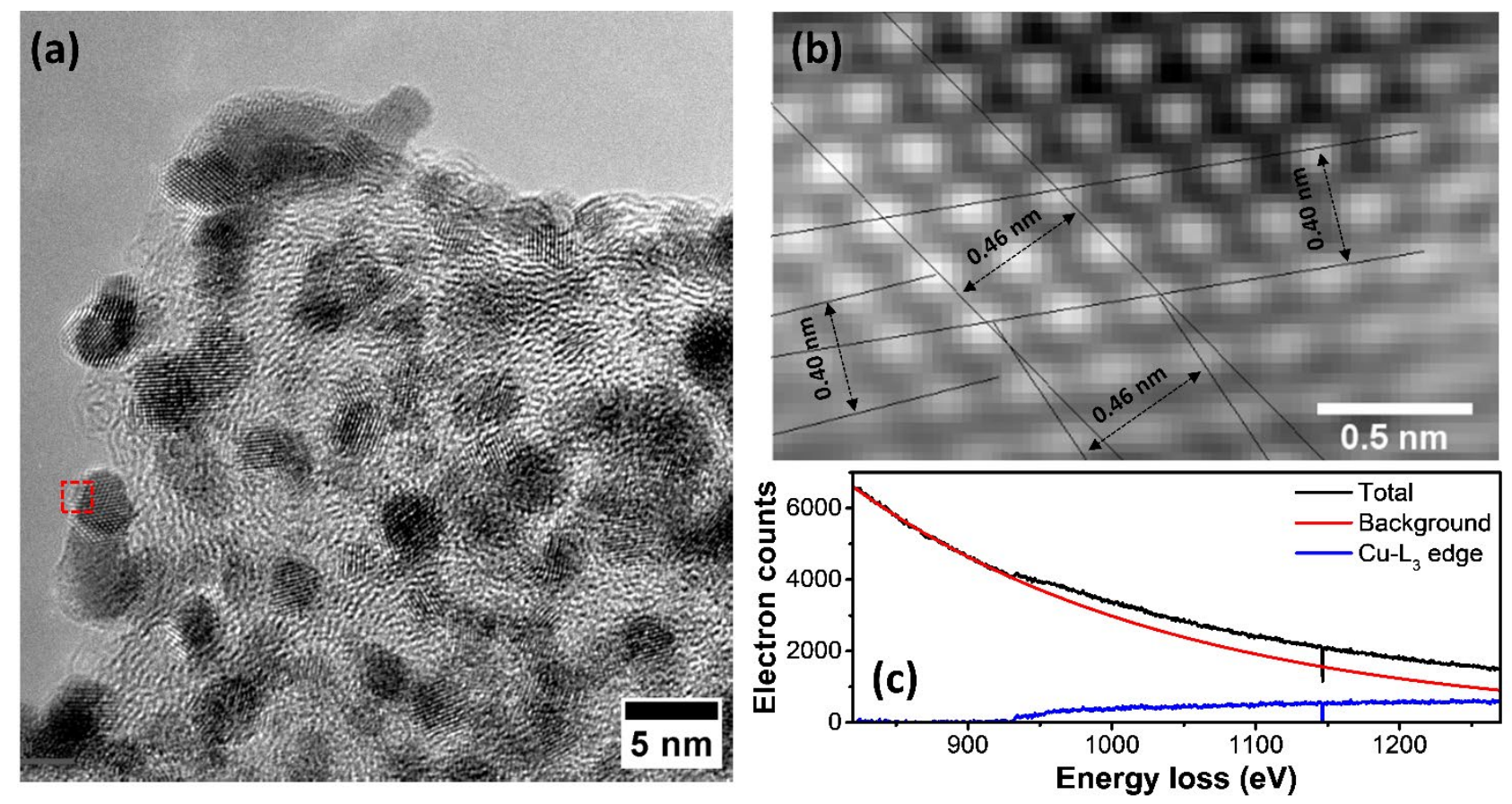

Fig. 5: (a) HRTEM image of the Pt/C standard electrode electrochemically treated by potential cycling in $0.1 \mathrm{M} \mathrm{HCl}+0.01 \mathrm{M} \mathrm{CuCl}_{2}$ for 2 cycles between 0.4 and $1.6 \mathrm{~V}$ (scan rate: $100 \mathrm{mV} / \mathrm{s}$; end potential: $0.4 \mathrm{~V}$ ), revealing the presence of carbon supported Pt nanoparticles. (b) Inverse FFT (IFFT) image of Pt-nanoparticle portion (enclosed in rectangle in (a)) showing lattice fringes corresponding to Pt (111) and Pt (200) crystallographic planes with respective lattice spacing values of 0.23 and $0.20 \mathrm{~nm}$. (c) Electron energy loss spectrum of the $\mathrm{Pt} / \mathrm{C}$ sample (electrochemical treatment same to (a)) consisting of a weak edge at $\sim 931 \mathrm{eV}$ corresponding to $\mathrm{Cu}$, confirming the presence of $\mathrm{Cu}$.

Effect of $\mathrm{Cu}^{2+}$ in different electrolytes: The effect of the presence of $\mathrm{Cu}^{2+}$ on the $\mathrm{Pt}$ dissolution under different conditions is demonstrated in Fig. 6 and Fig. 7. The Pt-dissolution shows significant enhancement in the presence of $\mathrm{Cu}$ ions, both in the presence of a complexing agent such as $\mathrm{Cl}^{-}$ions 
or in their absence. As shown in Fig. 6a, in presence of $\mathrm{Cl}^{-}$as a Pt-complexing agent $\left(\mathrm{H}^{+}: 0.1 \mathrm{M} ; \mathrm{Cl}^{-}\right.$ : $0.1 \mathrm{M}) \sim 60 \%$ of the $\mathrm{Pt}$ on the electrode dissolves in 25 potential cycles $(0.4-1.6 \mathrm{~V} ; 100 \mathrm{mV} / \mathrm{s})$, suggesting a high rate of dissolution due to formation of $\mathrm{Pt}-\mathrm{Cl}$ complexes. Under similar conditions, with addition of $\mathrm{Cu}^{2+}\left(\mathrm{H}^{+}: 0.1 \mathrm{M} ; \mathrm{Cl}^{-}: 0.1 \mathrm{M} ; \mathrm{Cu}^{2+}: 0.01 \mathrm{M}\right)$ the inhibition of the redeposition enhances the dissolution to $\sim 75 \%$ along with a relatively smaller increase of average crystallite size/\%dissolution (shown as third y-axis in Fig. 6a). The corresponding XRD patterns of postdissolution electrodes with/without $\mathrm{Cu}^{2+}$ are shown in Fig. $6 \mathrm{~b}$, with the average crystallite sizes being $3.3 \mathrm{~nm}$ for pristine electrode, $5.0 \mathrm{~nm}$ for post-dissolution electrode without $\mathrm{Cu}^{2+}$ (\%dissolution: $\sim 61 \%$ ) and $4.8 \mathrm{~nm}$ for post-dissolution electrode with $\mathrm{Cu}^{2+}$ (\%dissolution: $\sim 75 \%$ ). However, the numbers, being uncertain due to factors such as low intensity of XRD peaks for postdissolution samples, uncorrected instrumental broadening, etc., provide qualitative variation of the crystallite size. Similarly, the average particle sizes of pristine and post-dissolution electrodes through TEM analysis (Fig. 6d-f) suggest smaller increase of average particle size/\%dissolution (average particle sizes: (i) pristine: $2.5 \mathrm{~nm}$, (ii) post-dissolution without $\mathrm{Cu}^{2+}: 3.1 \mathrm{~nm}$ and (iii) postdissolution with $\mathrm{Cu}^{2+}: 3.20 \mathrm{~nm}$ ). Hence, presence of $\mathrm{Cu}^{2+}$ during potential cycling seems to inhibit the redeposition through cyclic formation and removal of a $\mathrm{Cu}$-adlayer on the $\mathrm{Pt}$ surface such that the Pt surface remains open for Pt dissolution but becomes inaccessible for redeposition. Fig. 6c shows the effect of different lower potentials $(0.2,0.4$ and $0.6 \mathrm{~V}$; with a fixed upper potential limit of $1.6 \mathrm{~V}$ ) on dissolution of platinum through potential cycling. In the absence of $\mathrm{Cu}^{2+}$ as SSS, the decrease of \%dissolution with decreasing lower potential is attributed to the redeposition of dissolved Pt species. On the other hand, in the presence of $\mathrm{Cu}^{2+}$ as SSS, the inhibition of redeposition helps maintaining a comparatively constant \%dissolution when decreasing the lower potential from 0.4 to $0.2 \mathrm{~V}$. In addition, a lower \%dissolution for both cases (with/without SSS) in the case of a lower potential value of $0.6 \mathrm{~V}$ may be attributed to the incomplete dissolution of the 
Pt-oxide layer formed during higher $(>1.0 \mathrm{~V})$ potentials. As the formation of Pt-Oxides during positive-going scan and their subsequent reduction during negative-going scan is the dominant dissolution mechanism during potentiodynamic treatment, an upper potential limit $>1.0 \mathrm{~V}$ is required for efficient dissolution [47]. This confirms the requirement of the lower potential limit to be below $0.6 \mathrm{~V}$ and the higher potential limit to be above $1.0 \mathrm{~V}$. 


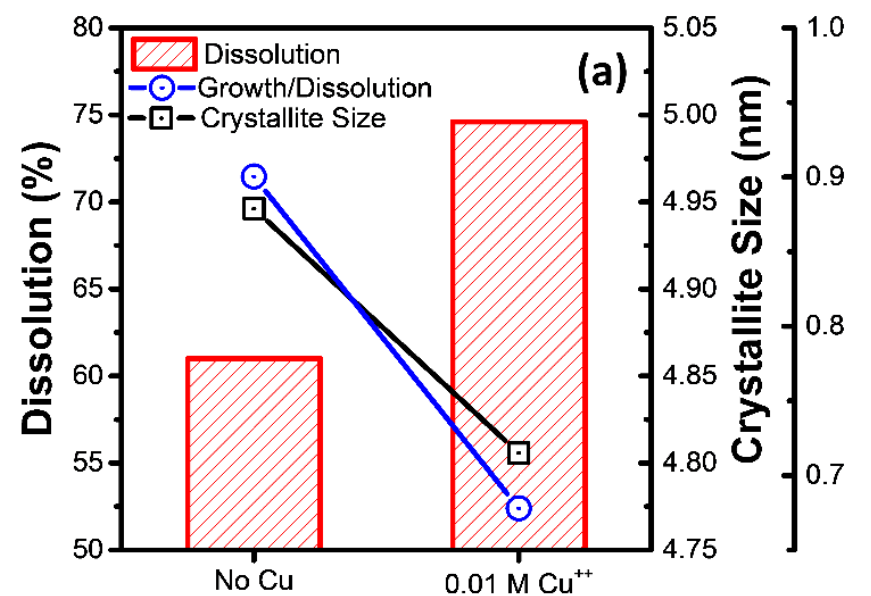

Exp. Condition
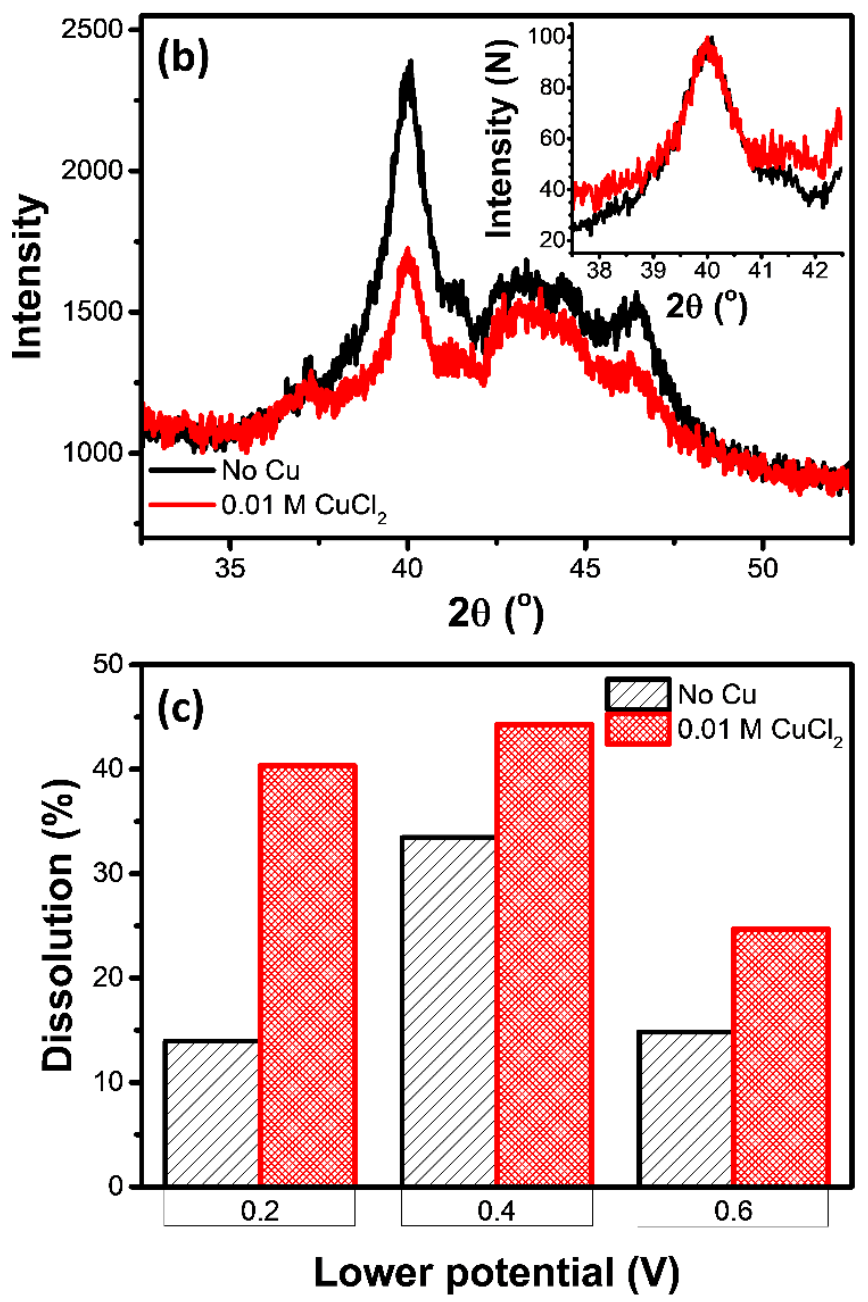
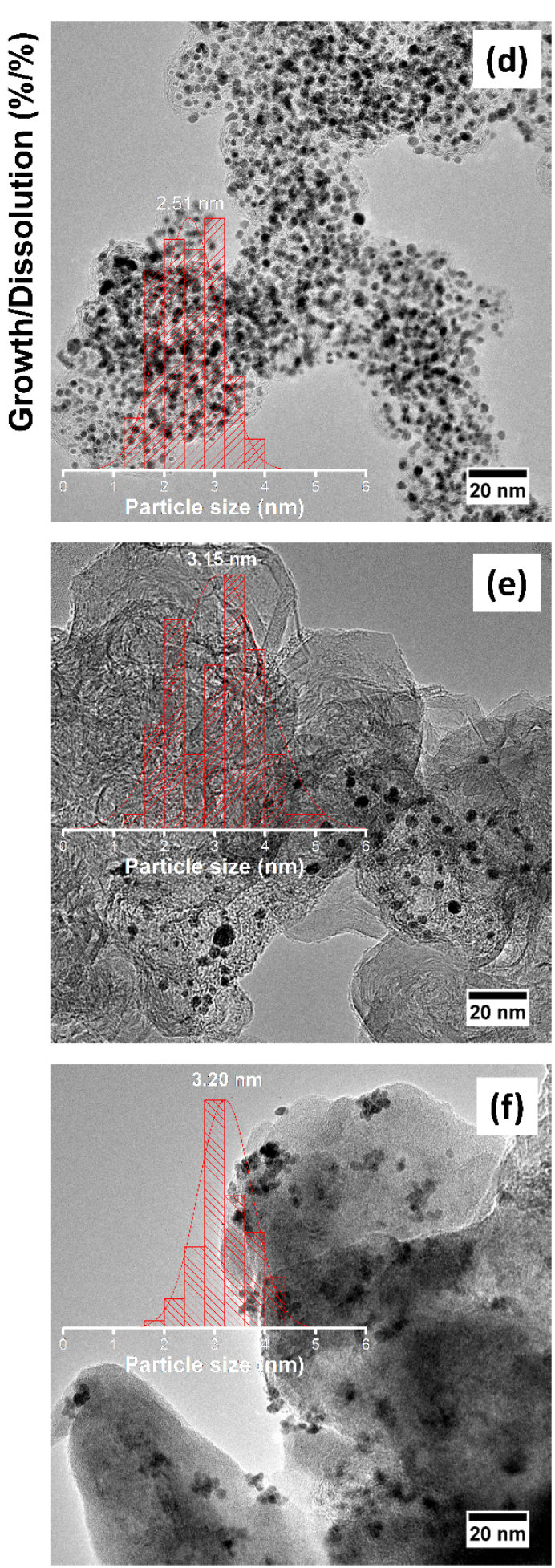

Fig. 6: Effect of presence of $\mathrm{Cu}^{2+}$ as SSS on the Pt-dissolution efficiency in electrolytes containing ions capable of Pt-complex formation. (a) Variations of \%dissolution, crystallite size and crystallite \%growth/\%dissolution (third y-axis) for $\mathrm{Pt} / \mathrm{C}$ standard electrodes 
subjected to potential cycling in $\mathrm{Cu}-$ free $(0.1 \mathrm{M} \mathrm{HCl})$ and $\mathrm{Cu}$-containing (0.1 $\mathrm{M} \mathrm{HCl}+0.01 \mathrm{M}$ $\mathrm{CuCl}_{2}$ ) electrolytes containing $\mathrm{Cl}^{-}$as $\mathbf{P t}$-complexing ions (50 potential cycles between 0.4 and $1.6 \mathrm{~V}$; scan rate: $100 \mathrm{mV} / \mathrm{s}$ ). (b) XRD patterns of the electrochemically treated electrodes (Inset: intensity normalized Pt (111) diffraction peaks). Lower absolute intensity of the XRD pattern corresponding to the electrode treated in presence of $\mathrm{Cu}^{2+}$ may be attributed to the lower residual Pt-loading on the electrode due to high \%dissolution. (c) Variations of \%dissolution from Pt/C standard electrode with lower potential limit during electrochemical treatment ( 25 cycles; scan rate- $100 \mathrm{mV} / \mathrm{s}$; upper potential- $1.6 \mathrm{~V})$ in $\mathrm{Cu}$-free $(0.1 \mathrm{M} \mathrm{HCl}$ ) and Cu-containing (0.1 M HCl+0.01 $\mathrm{M} \mathrm{CuCl}_{2}$ ) electrolytes. (d-f) TEM images of $\mathbf{P t} / \mathrm{C}$ electrodes (specification: same as of (a)) showing Pt nanoparticle distribution in (d) pristine Pt/C catalyst and in the electrodes electrochemically treated as described in (a) with (e) and (f) corresponding respectively to $0.1 \mathrm{M} \mathrm{HCl}$ and $0.1 \mathrm{M} \mathrm{HCl}+0.01 \mathrm{M} \mathrm{CuCl}_{2}$ electrolytes. Insets of TEM images (d-f) show corresponding particle size distribution histograms.

The effect of inhibition of redeposition on the Pt-dissolution in non-complexing electrolytes has been demonstrated in Fig. 7. The increased \%dissolution and the decreased crystallite size growth/dissolution (Fig. 7a) during potential cycling in presence of $\mathrm{Cu}^{2+}$ as compared to their corresponding values in absence of $\mathrm{Cu}^{2+}$ confirm the mechanism proposed in Fig. 1b, the inhibition of redeposition and the exposure of $\mathrm{Pt}$ surface when relevant in the presence of $\mathrm{Cu}^{2+}$ as SSS. Again, similar conclusions can be drawn from Fig. 7c-d, showing the surface switching effect during potential cycling for 3000 cycles in $1 \mathrm{M} \mathrm{HNO}_{3}$ as the non-complexing, yet stronger oxidizing electrolyte, and $0.1 \mathrm{M} \mathrm{Cu}\left(\mathrm{NO}_{3}\right)_{2}$ as the $\mathrm{Cu}^{2+}$ source. In the presence of $\mathrm{Cu}^{2+}$, electrochemical potential cycling exhibits a $\sim 2.5$ fold enhancement of $\%$ dissolution along with $\sim 25 \%$ less growth of crystallite size for both of the non-complexing electrolytes. 


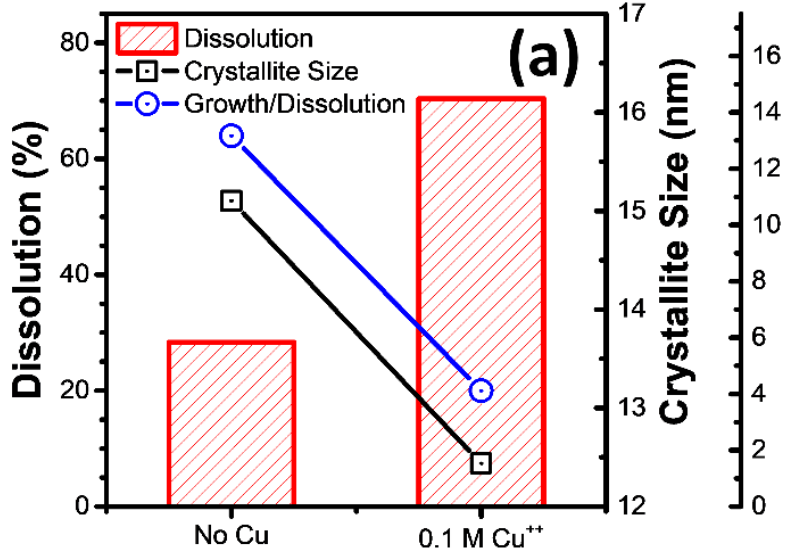

Exp. Condition

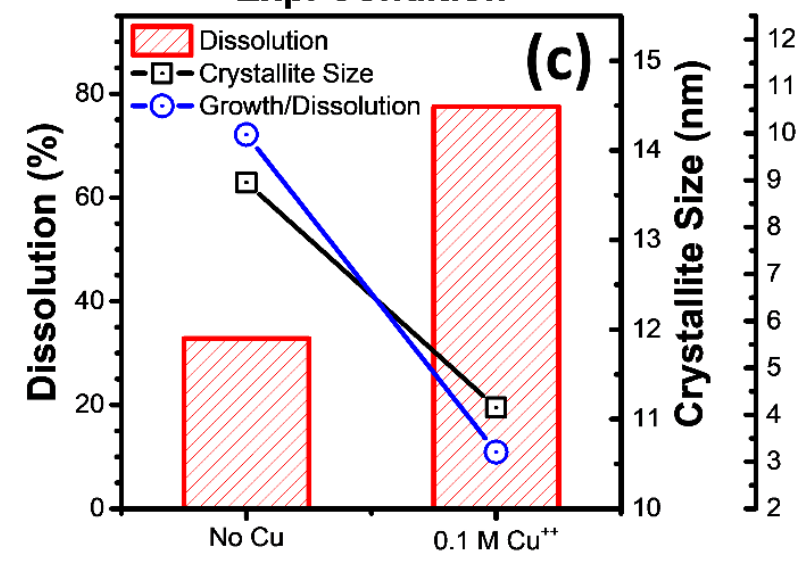

Exp. Condition
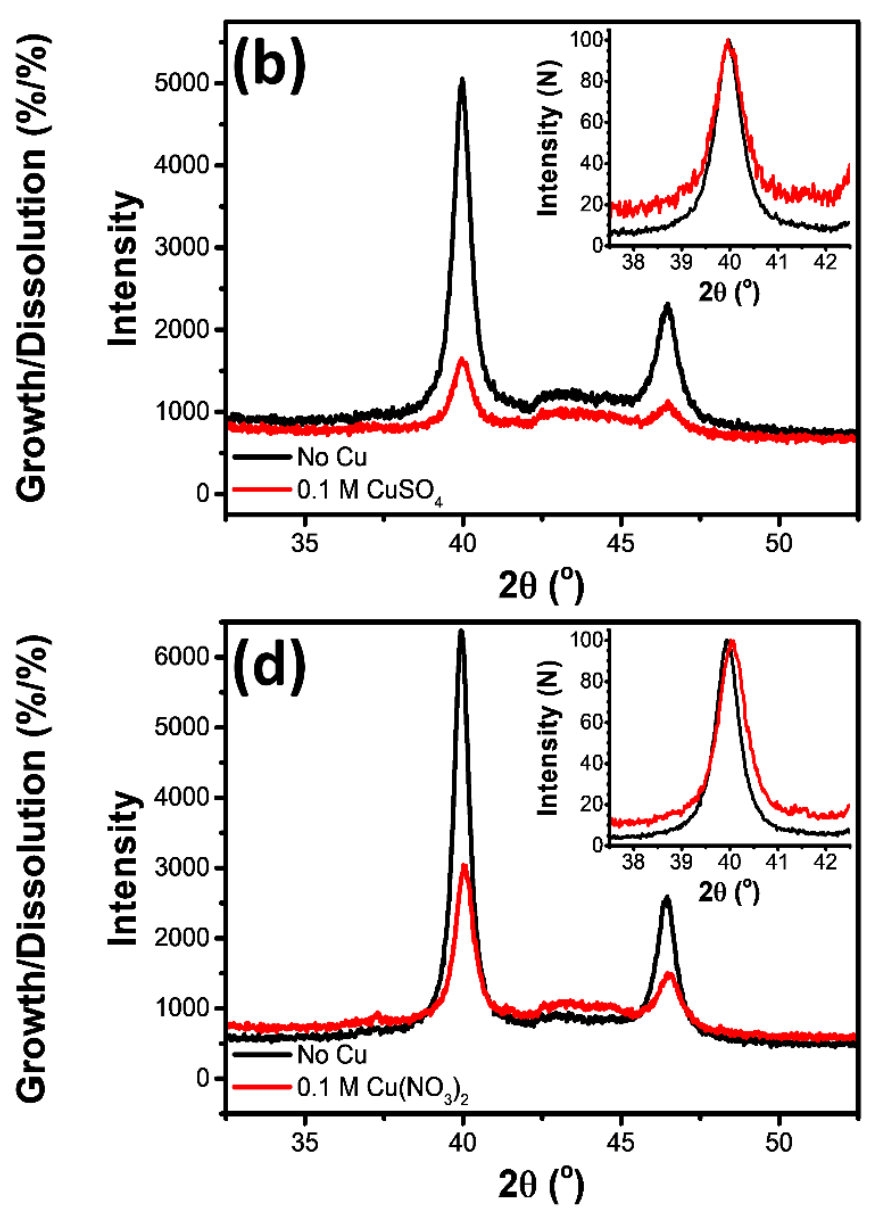

Fig. 7: Effect of presence of $\mathrm{Cu}^{2+}$ as SSS on the Pt-dissolution efficiency in non-complexing electrolytes. (a) and (c) show variations of the \%dissolution, crystallite size and crystallite \%growth/\%dissolution (shown as third y-axis) for $\mathrm{Pt} / \mathrm{C}$ standard electrodes subjected to electrochemical dissolution treatment in $\mathrm{Cu}$-free and $\mathrm{Cu}$-containing electrolytes. The electrochemical dissolution treatment involved a potential cycling between 0.4 and $1.6 \mathrm{Vat}$ a

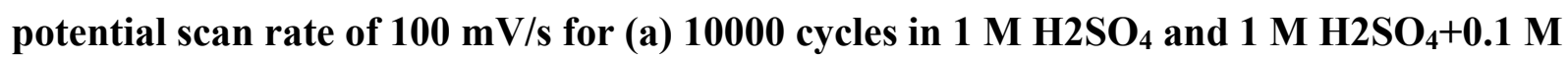
$\mathrm{CuSO}_{4}$ electrolytes; for (c) 3000 cycles in $1 \mathrm{M} \mathrm{HNO}_{3}$ and $1 \mathrm{M} \mathrm{HNO}_{3}+0.1 \mathrm{M} \mathrm{Cu}\left(\mathrm{NO}_{3}\right)_{2}$ electrolytes. XRD patterns of the electrochemically treated electrodes corresponding to (a) and (c) are shown in (b) and (d), respectively. The corresponding intensity normalized Pt (111) diffraction peaks for the electrodes have been shown as insets of (b) and (d). Lower XRD 


\section{peak intensities for the electrodes treated in presence of $\mathrm{Cu}^{2+}$ is attributed to their comparatively lower amount of undissolved Pt.}

The electrochemical treatment of $\mathrm{Pt} / \mathrm{C}$ in complexing or non-complexing electrolytes leads to the growth of crystallite size irrespective of the presence or absence of $\mathrm{Cu}^{2+}$. However, lower relative growth of crystallite size and higher \%dissolution in presence of SSS, along with the fact that the crystallite size increases with \%dissolution in absence of SSS, confirm the successful inhibition of Pt redeposition and accessibility of fresh Pt surface by SSS without hindering the dissolution process. Again, the slight growth of crystallites despite the presence of $\mathrm{Cu}^{2+}$ as the inhibitor for redeposition may be attributed to an incomplete inhibition of Pt redeposition. This may be attributed primarily to the fact that formation of $\mathrm{Cu}$-adlayer by $\mathrm{Cu}-\mathrm{UPD}$ takes place over a broad potential range during the negative-going scan, which makes a fraction of the Pt-surface accessible for Pt redeposition. Hence, an ideal SSS should be able to curb this parallel process. Other metal ions, for example, having suitable reduction potential may be employed as SSS (e.g., $\mathrm{Cu}{ }^{+}+e^{-} \rightarrow \mathrm{Cu}$; $\mathrm{E}^{\mathrm{o}}=$ $0.521 \mathrm{~V}$ is suitable for Pt (supplementary information: S3 and S4). However, use of the most stable $\mathrm{Cu}$ cation is preferred as oxidation of the deposited $\mathrm{Cu}$ on $\mathrm{Pt}$ from $\mathrm{Cu}^{+}$during first positive-going scan will form the more stable oxidation state $\left(\mathrm{e} . \mathrm{g} . \mathrm{Cu}^{2+}\right)$. Moreover, the enhancement of dissolution has been observed for two different concentrations of the SSS $\left(\mathrm{Cu}^{2+}\right)$. For example, the Pt concentration/time study (Fig. 4) and the potential limit study (Fig. 6c) are performed with a $\mathrm{Cu}^{2+}$ concentration of $0.01 \mathrm{M}$ instead of the $\mathrm{Cu}^{2+}$ concentration of $0.1 \mathrm{M}$ used more frequently in the other experiments of the study. As the amount of available SSS $\left(\mathrm{Cu}^{2+}\right)$ should be sufficient to cover the Pt surface during the negative-going scan, the minimum SSS concentration depends on factors such as the electrochemically active surface area of the electrode, the scan rate, the diffusivity of the SSS in the electrolyte, etc. 
In principle, the inhibition effect through SSS (e.g. $\mathrm{Cu}^{2+}$ ) may be applied to other metals using appropriate SSS, having suitable redox potential and compatibility towards formation of surface adlayer. For example, effect of presence of $\mathrm{Cu}^{2+}$ on dissolution of $\mathrm{Au}$ through potential cycling in $\mathrm{HCl}$ has been studied using an $\mathrm{Au}$ wire $(0.1 \mathrm{~mm}$ diameter $)$ electrode as working electrode. Similar to $\mathrm{Pt}, \mathrm{Au}$ shows enhanced dissolution in presence of $\mathrm{Cu}^{2+}$ due to inhibition of redeposition of dissolved Au species $\left(\mathrm{Au}^{3+}\right.$ supplementary information S2, S5). Finally, for the electrochemical dissolution process to be feasible for practical applications, high \%dissolution $(\sim 100 \%)$ is desired. However, due to growth of particles during dissolution process, the rate of dissolution decreases with increasing number of potential cycles. Use of SSS may provide such high dissolutions ( $>95 \%)$ within significantly lesser $(<50 \%)$ number of potential cycles required otherwise (supplementary information S6). Hence, the inhibition of redeposition through SSS may improve the industrial feasibility of the electrochemical recycling of PGMs.

\section{Conclusions}

Here, we introduce a new concept for platinum electrochemical dissolution by using an intelligent surface switching species (SSS), as an environmentally friendly, efficient and economic process for recovery of platinum nanoparticulate. We have demonstrated the effect of $\mathrm{Cu}$-ions as a SSS for enhancement of dissolution of nanoparticulate Pt through electrochemical potential cycling. For negative-going scan (increasingly reducing potentials applied), the Pt surface is blocked through $\mathrm{Cu}-\mathrm{UPD}$; while for positive-going scan (increasingly oxidizing potentials applied), $\mathrm{Cu}$ strips away at potentials much lower than the Pt-oxidation potentials. The SSS enhances Pt dissolution significantly by inhibiting the crystallite growth through redeposition of dissolved Pt species, which 
becomes intense for reducing potentials during negative-going scan and increases with the concentration of dissolved Pt species in electrolyte. We have observed that the dissolution process is improved by a factor of 2 or more with relatively low Pt crystallite growth in various electrolytes with/without Pt-complexing species. This leads to an overall dissolution efficiency of more than 95\%. The SSS concept can be expanded to other metallurgical processing (e.g. this work have also demonstrated $\mathrm{Au}$ ). By selecting an appropriate SSS, the technology may be used at industrial scales for efficient recovery of various precious metals.

\section{Acknowledgement}

The authors appreciate the financial support from VILLUM FONDEN's blokstipendier program. The authors greatly appreciate EWII fuel cell $\mathrm{A} / \mathrm{S}$ for providing the $\mathrm{Pt} / \mathrm{C}$ standard electrode samples used for the dissolution study.

\section{Competing interests}

S.M.A and R.S. are inventors on EU patent application EP 18170312.5 , submitted by University of Southern Denmark, which covers the herein-described PGM recovery process. Other authors declare no competing interests.

\section{Supplementary Materials}

S1: Cyclic voltammograms and potential profiles used for electrochemical treatment; S2:

Characterizations; S3: Inhibition effect using $\mathrm{Cu}^{+}$as surface switching species (SSS); S4: Effect of 
other metal ions on Pt dissolution; S5: Effect of $\mathrm{Cu}$ inhibition on other precious metals (PMs); S6: Effectiveness for industrial applications

\section{References}

[1] B. Guan, R. Zhan, H. Lin, Z. Huang, Review of state of the art technologies of selective catalytic reduction of NOx from diesel engine exhaust, Appl. Therm. Eng., 66 (2014) 395-414. [2] Y. Leng, G. Chen, A.J. Mendoza, T.B. Tighe, M.A. Hickner, C.-Y. Wang, Solid-State Water Electrolysis with an Alkaline Membrane, J. Am. Chem. Soc., 134 (2012) 9054-9057.

[3] K.E. Ayers, J.N. Renner, N. Danilovic, J.X. Wang, Y. Zhang, R. Maric, H. Yu, Pathways to ultra-low platinum group metal catalyst loading in proton exchange membrane electrolyzers, Catalysis Today, 262 (2016) 121-132.

[4] S. Sui, X. Wang, X. Zhou, Y. Su, S. Riffat, C.-j. Liu, A comprehensive review of Pt electrocatalysts for the oxygen reduction reaction: Nanostructure, activity, mechanism and carbon support in PEM fuel cells, J. Mater. Chem. A, 5 (2017) 1808-1825.

[5] S. Litster, G. McLean, PEM Fuel Cell Electrodes, J. Power Sources, 130 (2004) 61-76.

[6] Z.P. Cano, D. Banham, S. Ye, A. Hintennach, J. Lu, M. Fowler, Z. Chen, Batteries and fuel cells for emerging electric vehicle markets, Nature Energy, 3 (2018) 279-289.

[7] T. Kelly, G. Matos, D. with Buckingham, C. DiFrancesco, K. Porter, C. Berry, M. Crane, T. Goonan, J. Sznopek, Historical statistics for mineral and material commodities in the United States, Data SeriesReston, VA, 2005.

[8] G.M. Mudd, S.M. Jowitt, T.T. Werner, Global platinum group element resources, reserves and mining - A critical assessment, Sci. Total Environ., 622-623 (2018) 614-625. 
[9] R. Jones, An overview of Southern African PGM smelting, Nickel and Cobalt 2005: Challenges in Extraction and Production, 44th Annual Conference of MetallurgistsCalgary, Alberta, Canada, 2005, pp. 147-178.

[10] R.S. Marinho, J.C. Afonso, J.W.S.D. da Cunha, Recovery of platinum from spent catalysts by liquid-liquid extraction in chloride medium, J. Hazard. Mater., 179 (2010) 488-494.

[11] F. Kodera, Y. Kuwahara, A. Nakazawa, M. Umeda, Electrochemical corrosion of platinum electrode in concentrated sulfuric acid, J. Power Sources, 172 (2007) 698-703.

[12] M.K. Jha, J.-c. Lee, M.-s. Kim, J. Jeong, B.-S. Kim, V. Kumar, Hydrometallurgical recovery/recycling of platinum by the leaching of spent catalysts: A review, Hydrometallurgy, 133 (2013) 23-32.

[13] N. Hodnik, C. Baldizzone, G. Polymeros, S. Geiger, J.-P. Grote, S. Cherevko, A. Mingers, A. Zeradjanin, K.J.J. Mayrhofer, Platinum recycling going green via induced surface potential alteration enabling fast and efficient dissolution, Nature Communications, 7 (2016) 13164. [14] G. Benke, W. Gnot, The electrochemical dissolution of platinum, Hydrometallurgy, 64 (2002) 205-218.

[15] L. R., N. E., K.G.J. M., Environmentally Friendly Carbon - Preserving Recovery of Noble Metals From Supported Fuel Cell Catalysts, ChemSusChem, 8 (2015) 1926-1934.

[16] C.J. A., F. R., Polytetrafluoroethylene decomposition in air and nitrogen, Polymer Engineering \& Science, 41 (2001) 2137-2147.

[17] M.A. Barakat, M.H.H. Mahmoud, Recovery of platinum from spent catalyst, Hydrometallurgy, 72 (2004) 179-184.

[18] D. Jimenez de Aberasturi, R. Pinedo, I. Ruiz de Larramendi, J.I. Ruiz de Larramendi, T. Rojo, Recovery by hydrometallurgical extraction of the platinum-group metals from car catalytic converters, Miner. Eng., 24 (2011) 505-513. 
[19] X. Wang, R. Kumar, D.J. Myers, Effect of Voltage on Platinum Dissolution: Relevance to Polymer Electrolyte Fuel Cells, Electrochem. Solid-State Lett., 9 (2006) A225-A227.

[20] P. Jovanovič, U. Petek, N. Hodnik, F. Ruiz-Zepeda, M. Gatalo, M. Šala, V.S. Šelih, T.P. Fellinger, M. Gaberšček, Importance of non-intrinsic platinum dissolution in $\mathrm{Pt} / \mathrm{C}$ composite fuel cell catalysts, Physical Chemistry Chemical Physics, 19 (2017) 21446-21452.

[21] P.J. Ferreira, G.J. la O', Y. Shao-Horn, D. Morgan, R. Makharia, S. Kocha, H.A. Gasteiger, Instability of Pt / C Electrocatalysts in Proton Exchange Membrane Fuel Cells: A Mechanistic Investigation, J. Electrochem. Soc., 152 (2005) A2256-A2271.

[22] M. Chourashiya, R. Sharma, S.M. Andersen, Accurate Determination of Catalyst Loading on Glassy Carbon Disk and Its Impact on Thin Film Rotating Disk Electrode for Oxygen Reduction Reaction, Analytical Chemistry, 90 (2018) 14181-14187.

[23] A. Pavlišič, P. Jovanovič, V.S. Šelih, M. Šala, N. Hodnik, M. Gaberšček, Platinum Dissolution and Redeposition from Pt/C Fuel Cell Electrocatalyst at Potential Cycling, Journal of The Electrochemical Society, 165 (2018) F3161-F3165.

[24] S. Søren Bredmose, W. Yan, J. Jens Oluf, Z. Wenjing, Coarsening of carbon black supported Pt nanoparticles in hydrogen, Nanotechnology, 28 (2017) 475710.

[25] Y. Shao-Horn, W.C. Sheng, S. Chen, P.J. Ferreira, E.F. Holby, D. Morgan, Instability of Supported Platinum Nanoparticles in Low-Temperature Fuel Cells, Top. Catal., 46 (2007) 285-305. [26] J.-P. Grote, A.R. Zeradjanin, S. Cherevko, K.J.J. Mayrhofer, Coupling of a scanning flow cell with online electrochemical mass spectrometry for screening of reaction selectivity, Rev. Sci. Instrum., 85 (2014) 104101.

[27] A. Pavlišič, P. Jovanovič, V.S. Šelih, M. Šala, N. Hodnik, S. Hočevar, M. Gaberšček, The influence of chloride impurities on $\mathrm{Pt} / \mathrm{C}$ fuel cell catalyst corrosion, Chemical Communications, 50 (2014) 3732-3734. 
[28] R. Sharma, S. Gyergyek, S.M. Andersen, Environmentally and Industrially Friendly Recycling of Platinum Nanoparticles Through Electrochemical Dissolution-Electrodeposition in AcidFree/Dilute Acidic Electrolytes, ChemSusChem, 11 (2018) 3742-3750.

[29] C.L. Scortichnini, C.N. Reilley, Surface characterization of Pt electrodes using underpotential deposition of $\mathrm{H}$ and $\mathrm{Cu}$ : Part I. Pt(100), Journal of Electroanalytical Chemistry and Interfacial Electrochemistry, 139 (1982) 233-245.

[30] D.M. Kolb, R. Kötz, K. Yamamoto, Copper monolayer formation on platinum single crystal surfaces: Optical and electrochemical studies, Surf. Sci., 87 (1979) 20-30.

[31] N.M. Markovic, H.A. Gasteiger, P.N. Ross, Jr., Copper Electrodeposition on Pt(111) in the Presence of Chloride and (Bi)sulfate: Rotating Ring-Pt(111) Disk Electrode Studies, Langmuir, 11 (1995) 4098-4108.

[32] I.M. Tidswell, C.A. Lucas, N.M. Marković, P.N. Ross, Surface-structure determination using anomalous X-ray scattering: Underpotential deposition of copper on $\operatorname{Pt}(111)$, Physical Review B, 51 (1995) 10205-10208.

[33] N.M. Marković, C.A. Lucas, H.A. Gasteiger, P.N. Ross, The structure of adsorbed bromide concurrent with the underpotential deposition (UPD) of Cu on Pt(111), Surf. Sci., 372 (1997) 239254.

[34] N.M. Markovic', B.N. Grgur, C.A. Lucas, P.N. Ross, UPD of Cu on Pt(100): effects of anions on adsorption isotherms and interface structures, Electrochim. Acta, 44 (1998) 1009-1017. [35] A.I. Danilov, E.B. Molodkina, A.V. Rudnev, Y.M. Polukarov, J.M. Feliu, Kinetics of copper deposition on $\operatorname{Pt}(111)$ and $\mathrm{Au}(111)$ electrodes in solutions of different acidities, Electrochim. Acta, 50 (2005) 5032-5043. 
[36] K. Christian, G. Konrad, W. Wolf, B. Michael, Synthesis of CuCorePtShell Nanoparticles as Model Structures for Core-Shell Electrocatalysts by Direct Platinum Electrodeposition on Copper, ChemPhysChem, 14 (2013) 1205-1210.

[37] S.R. Brankovic, J.X. Wang, R.R. Adžić, Metal monolayer deposition by replacement of metal adlayers on electrode surfaces, Surf. Sci., 474 (2001) L173-L179.

[38] J. Zhang, F.H.B. Lima, M.H. Shao, K. Sasaki, J.X. Wang, J. Hanson, R.R. Adzic, Platinum Monolayer on Nonnoble Metal-Noble Metal Core-Shell Nanoparticle Electrocatalysts for O2 Reduction, The Journal of Physical Chemistry B, 109 (2005) 22701-22704.

[39] J.C. Meier, C. Galeano, I. Katsounaros, J. Witte, H.J. Bongard, A.A. Topalov, C. Baldizzone, S. Mezzavilla, F. Schüth, K.J.J. Mayrhofer, Design criteria for stable Pt/C fuel cell catalysts, Beilstein Journal of Nanotechnology, 5 (2014) 44-67.

[40] L.M. Roen, C.H. Paik, T.D. Jarvi, Electrocatalytic Corrosion of Carbon Support in PEMFC Cathodes, Electrochem. Solid-State Lett., 7 (2004) A19-A22.

[41] X.-C. Liu, G.-C. Wang, R.-P. Liang, L. Shi, J.-D. Qiu, Environment-friendly facile synthesis of Pt nanoparticles supported on polydopamine modified carbon materials, J. Mater. Chem. A, 1 (2013) 3945-3953.

[42] P. Vanysek, Electrochemical series, in: D.R. Lide (Ed.) CRC handbook of chemistry and physics, CRC Press, Boca Raton, FL, 2005, pp. 8-23-28-33.

[43] D.J. Myers, X. Wang, M.C. Smith, K.L. More, Potentiostatic and Potential Cycling Dissolution of Polycrystalline Platinum and Platinum Nano-Particle Fuel Cell Catalysts, Journal of The Electrochemical Society, 165 (2018) F3178-F3190.

[44] L. Xing, G. Jerkiewicz, D. Beauchemin, Ion exchange chromatography coupled to inductively coupled plasma mass spectrometry for the study of Pt electro-dissolution, Analytica Chimica Acta, 785 (2013) 16-21. 
[45] B.R. Shrestha, E. Tada, A. Nishikata, Effect of Chloride on Platinum Dissolution, Electrochimica Acta, 143 (2014) 161-167.

[46] Y. Verde-Gómez, G. Alonso-Nuñez, F. Cervantes, A. Keer, Aqueous solution reaction to synthesize ammonium hexachloroplatinate and its crystallographic and thermogravimetric characterization, Materials Letters, 57 (2003) 4667-4672.

[47] H. Angerstein-Kozlowska, B.E. Conway, W.B.A. Sharp, The real condition of electrochemically oxidized platinum surfaces: Part I. Resolution of component processes, Journal of Electroanalytical Chemistry and Interfacial Electrochemistry, 43 (1973) 9-36.

[48] Y. Liu, D. Gokcen, U. Bertocci, T.P. Moffat, Self-Terminating Growth of Platinum Films by Electrochemical Deposition, Science, 338 (2012) 1327-1330.

[49] Y. Grunder, Q.M. Ramasse, R.A.W. Dryfe, A facile electrochemical route to the preparation of uniform and monoatomic copper shells for gold nanoparticles, PCCP, 17 (2015) 5565-5568. 
Table of Contents (TOC)
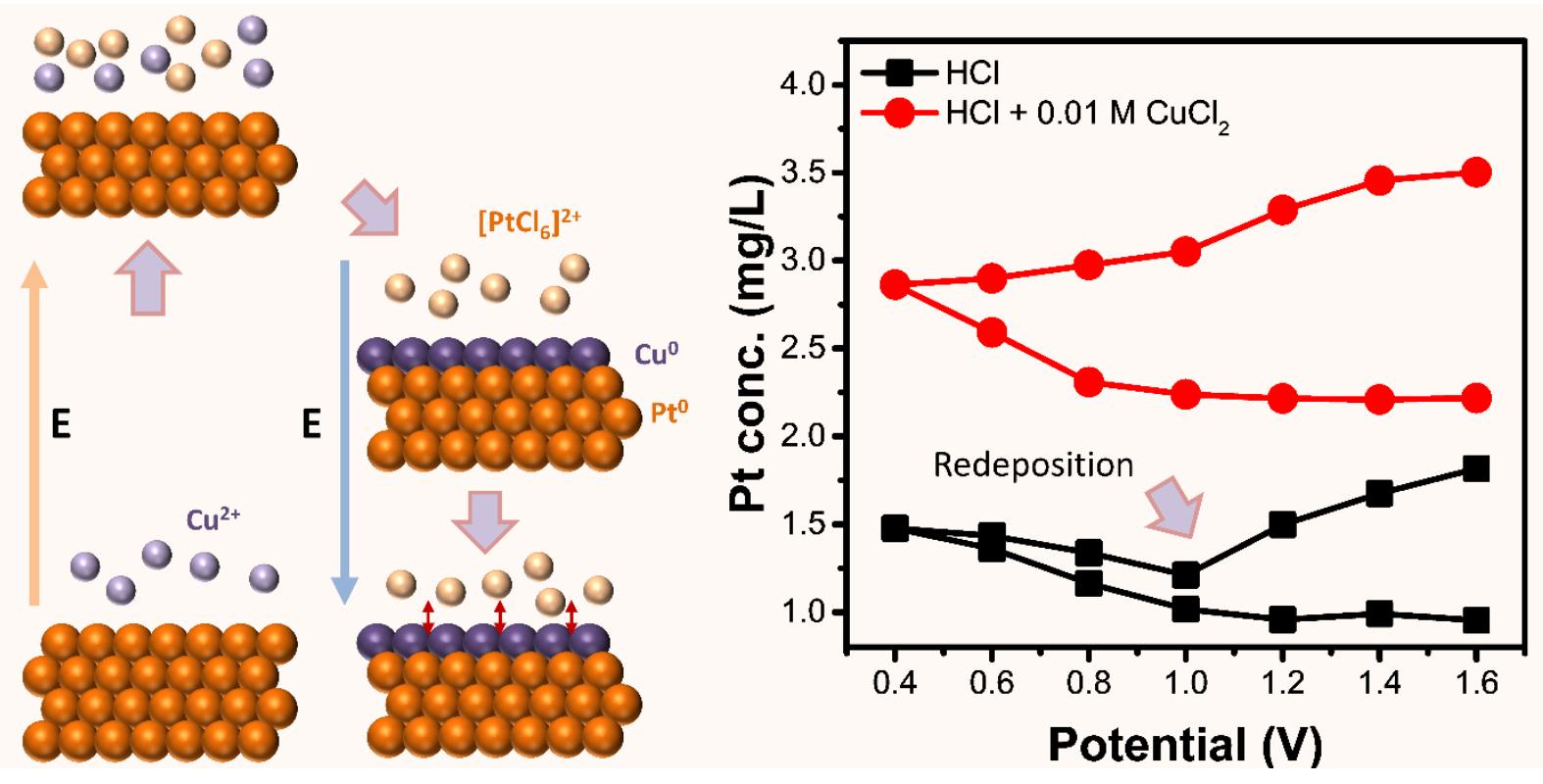